\title{
7. ALBIAN-CENOMANIAN DINOFLAGELLATE CYSTS FROM SITES 627 AND 635, LEG 101, BAHAMAS 1
}

\author{
Edwige Masure ${ }^{2}$
}

\begin{abstract}
The Albian-Cenomanian sediments in Holes 627B and 635B contain diverse dinoflagellate-cyst assemblages, which show affinities with coeval assemblages from offshore Morocco and northwest Europe. A total of 34 samples were analyzed from the shallow-water platform sediments and neritic marly chalk of Hole 627B and from the argillaceous chalk and limestone of Hole 635B. Dinoflagellate cysts indicate that the top of the shallow-water platform drilled at Hole 627B must be attributed to the late Albian. Dinocysts also date the drowning of the carbonate platform of the Blake Plateau. This drowning started in the latest Albian (Vraconian) and continued into the Cenomanian. The site area changed from an inner to intermediate or outer(?) neritic environment. The area around Hole 635B from the late Albian appears to have been situated in a deeper environment than the area around Hole 627B during the same period. The new dinoflagellate-cyst species Compositosphaeridium? bahamaensis n. sp., Maghrebinia breviornata $\mathrm{n} . \mathrm{sp}$. , and Subtilisphaera? habibi n. sp. are described, and Pervosphaeridium truncatum is emended. Additional taxonomic remarks about other species are included.
\end{abstract}

\section{INTRODUCTION}

Holes 627B and 635B were drilled in the Bahamas area during Leg 101 (Fig. 1). Hole 627B is located on the southern Blake Plateau, on the northern continental slope of Little Bahama Bank at $27^{\circ} 38.1^{\prime} \mathrm{N}, 78^{\circ} 17.65^{\prime} \mathrm{W}$ in a water depth of $1025.5 \mathrm{~m}$. Hole $635 \mathrm{~B}$ is situated in the Northeast Providence Channel at $25^{\circ} 25.18^{\prime} \mathrm{N}, 77^{\circ} 19.98^{\prime} \mathrm{W}$ in a water depth of $3470 \mathrm{~m}$ (Austin, Schlager, et al., 1986).

One objective for Leg 101 was to explain the present topographic configuration of the platforms and troughs in the Bahamas and to date the drowning of the platform of southern Blake Plateau. Two hypotheses about their origin have been advanced. The graben hypothesis suggests that the present topography reflects underlying horsts and grabens developed during the separation of Africa and North America in the Late Triassic-Early Jurassic (Mullins and Lynts, 1977). The "megabank" hypothesis suggests a mid-Cretaceous drowning of a homogeneous carbonate platform or "megabank" (Sheridan et al., 1981). These authors identified a velocity discontinuity and correlated it with the boundary between shallow-water limestones (Aptian-Albian) and pelagic-hemipelagic carbonates (Cenomanian). The top of the inferred carbonate platform was not reached in Hole 635B, but this top was sampled in Hole 627B.

The 34 samples collected from Holes 627B and 635B were processed using standard palynological techniques. Most samples contain rich dinoflagellate-cyst assemblages, acritarchs, and rare sporomorphs. Preservation is good. In Hole 627B, 23 samples were collected from a 268 -m-thick Cretaceous sequence between Samples 101-627B-57X, CC and 101-627B-29X-2, 50-52 $\mathrm{cm}$. Most of these samples are from the interval between Cores 101-627B-49X and 101-627B-38X. In Hole 635B, 10 samples were collected from a $57-\mathrm{m}$ sequence between Samples 101635B-14R-3, 146-148 cm, and 101-635B-8R, CC. The examined samples are listed in the Appendix.

\footnotetext{
${ }^{1}$ Austin, J. A., Schlager, W., et al., 1986. Proc. ODP, Sci. Results, 101: College Station, TX (Ocean Drilling Program).

${ }^{2}$ Laboratoire de Micropaléontologie, CNRS, UA 319, Université Pierre et Marie Curie, 4 Place Jussieu, 75252 Paris Cedex 05, France.
}

The purpose of this study is (1) to identify the dinoflagellatecyst assemblages from Holes 627B and 635B, (2) to date the drowning of the carbonate platform of the Blake Plateau, and (3) to attempt to define the paleoenvironments of Holes 627B and $635 \mathrm{~B}$.

\section{RESULTS}

Most of the dinoflagellate cysts recovered here were previously reported from sediments of Albian-Cenomanian age in other parts of the world. Several zonations were proposed for the middle Cretaceous (Clarke and Verdier, 1967; Bujak and Williams, 1978; Habib, 1977; Foucher, 1980). Habib (1977) proposed three zones for the middle Albian to Cenomanian of western North Atlantic DSDP Sites 99, 100, 101, 105, 387, and 391. However, the diagnostic species Spinidinium vestitum, Spinidinium echinoideum, and Trithyrodinium suspectum noted by Habib were not observed during this study. Existing zonations could not be recognized here. Therefore, age assignments were based on first occurrences of selected species, whose ranges are known from the North Atlantic Ocean, from northwest Europe, and from the Mazagan Plateau, off the northwest African shore, DSDP Leg 79 (Below, 1984).

\section{HOLE 627B, SOUTHERN BLAKE PLATEAU NORTH OF LITTLE BAHAMA BANK}

Hole 627B is located at the base of the slope of the Little Bahama Bank, and its drilling penetrated the top of the middle Cretaceous "megabank." A total of $536 \mathrm{~m}$ of sediments was drilled, which ranged in age from late Albian to Miocene. Cretaceous sediments extend from 536 to $355 \mathrm{~m}$ in Cores 101-627B$60 \mathrm{X}$ through 101-627B-27X. From this interval, 24 samples were studied between Section 101-627B-57X, CC and Sample 101627B-29X-02, 50-52 cm. Four lithologic units were differentiated, from bottom to top, by shipboard scientists (Austin, Schlager, et al., 1986): Unit VI, the carbonate platform (three samples); Unit V, marls with terrigenous components (18 samples); Unit IV, porous limestones (no samples); and Unit III, chalks and oozes (three samples). The lithology appears to represent a sequence that deepens from a shallow-water dolostone and evaporite (Unit VI), followed abruptly by outer-shelf marls (Unit V), through a condensed section (Unit IV), into an oceanic-plateau chalk (Unit III). Shipboard paleontologists dated the top of the 


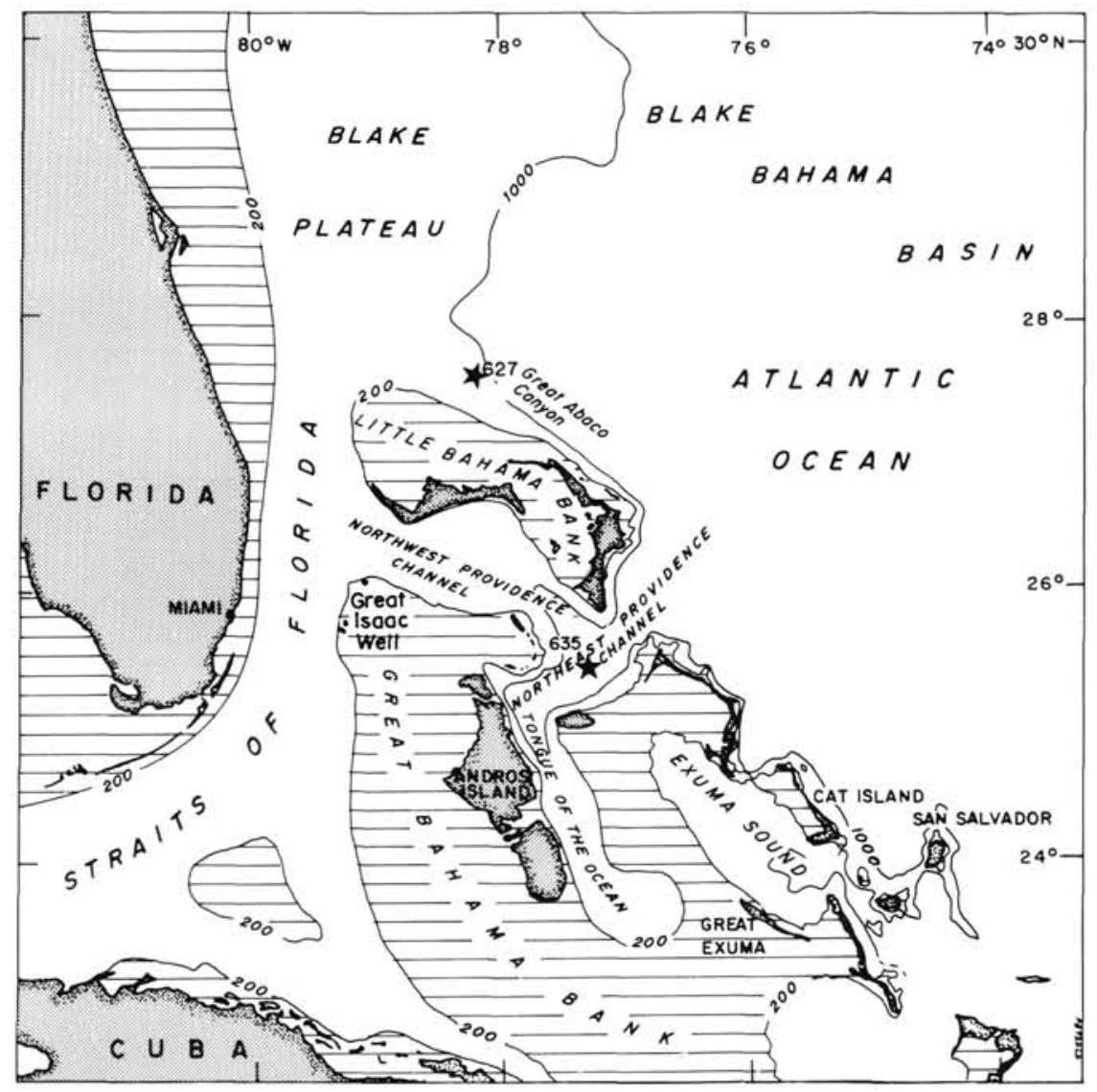

Figure 1. Location of Sites 627 and 635 in the Bahamas area. Bathymetry in meters.

platform (Unit VI) as late Albian (Core 101-627B-52X) using larger benthic foraminifers and dated the base of Unit $\mathrm{V}$ as latest Albian to early Cenomanian (Core 101-627B-49X) using calcareous nannofossils (Cores 101-627B-47X and 101-627B-45X) and planktonic foraminifers (Austin, Schlager, et al., 1986). The planktonic-foraminifer and calcareous-nannofossil zones correlated Cores 101-627B-38X and 101-627B-37X with the middle Cenomanian. Units IV and III are dated Coniacian-early Santonian (Core 101-627B-36X, using planktonic foraminifers) and Campanian (Cores 101-627B-34X through 101-627B-31X, using planktonic foraminifers and calcareous nannofossils), respectively.

\section{Biostratigraphy}

The distribution of the 67 taxa identified in Hole 627B is given in Figure 2. Full citations for all taxa are given in the "Taxonomy" section (this chapter).

\section{Unit VI (Cores 101-627B-60X through 101-627B-50X; $68 \mathrm{~m}$ )}

The three samples are located near the top of the platform; one sample (Section 101-627B-52X, CC) is barren. Many species found in the lowest sample (Section 101-627B-57X, CC) occur throughout the section. Stratigraphically useful forms include Dinopterygium cladoides, Xiphophoridium alatum, and Xenascus plotei. The oldest recorded occurrence of Dinopterygium cladoides is from the middle Albian. Xiphophoridium alatum is well known from the late Albian (Davey and Verdier, 1971; Williams and Bujak, 1985) but was reported in older sediments, in the upper part of the middle Albian of Boulonnais, France (Foucher, 1980). Xenasus plotei occurs in upper Albian sediments in DSDP Holes 545 and 547, drilled on the Mazagan Plateau (Below, 1984). Based on these ranges, a late Albian age is proposed for Section 101-627B-57X, CC. The upper, produc- tive Section 101-627B-54X, CC collected from the "megabank" contains the same dinoflagellate-cyst associations, apart from Cepadinium sp. BAHA (BAHA denotes "from Bahamas"); thus a late Albian age also is indicated.

\section{Unit V (Cores 101-627B-49X through 101-627B-37X; $124 \mathrm{~m}$ )}

Among the 18 samples collected in these sediments, five groups can be differentiated regarding the dinoflagellate-cyst assemblages and the first occurrence of the stratigraphically useful forms.

Samples 101-627B-49X-1, 29-31 cm, and 101-627B-49X-1, 9-11 cm: 14 species have their first occurrence in these samples, four of which are of stratigraphic interest. These are Cyclonephelium chabaca, Dapsilidinium laminaspinosum, Maghrebinia chleuh, and Maghrebinia perforata ssp. mirabilis (Fig. 2). The oldest recorded occurrence of Maghrebinia perforata (= Pterodininium perforata) is in the middle Albian of France (Davey and Verdier, 1971; Foucher, 1980). Cyclonephelium chabaca, Maghrebinia chleuh, and Maghrebinia perforata ssp. mirabilis occur in the latest Albian (Vraconian) and range into the Cenomanian in DSDP Holes 545 and 547A (Below, 1984). Both these species also occur in the latest Vraconian of the Ida and Tanane sections, Morocco (Below, 1981). A latest Albian (Vraconian) age can be assigned to Samples 101-627B-49X-1, 29-31 cm, and 101-627B-49X-1, 9-11 cm.

Samples 101-627B-47X-5, 50-52 cm, 101-627B-47X-3, 50-52 $\mathrm{cm}$, and 101-627B-46X-5, 50-52 cm: 11 species have their first stratigraphic occurrence in Sample 101-627B-47X-5, 50-52 cm. These include Achomosphaera sagena, Cribroperidinium intricatum, Litosphaeridium siphoniphorum ssp. siphoniphorum, Maghrebinia perforata ssp. perforata, and Maghrebinia breviornata $\mathrm{n} . \mathrm{sp}$. These species are characteristic of Vraconian assem- 


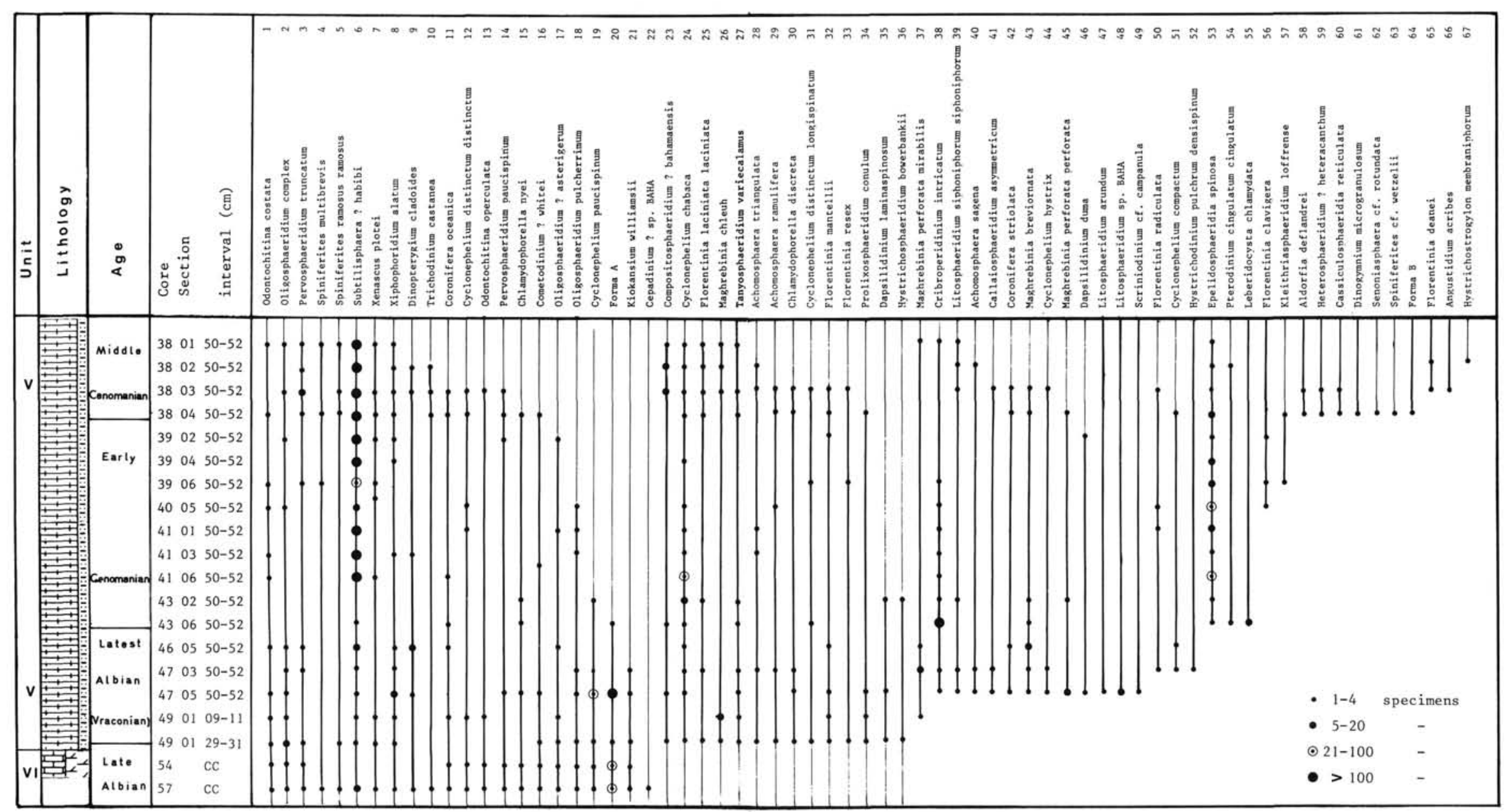

Figure 2. Distribution of dinoflagellate cysts in the mid-Cretaceous of Hole 627B. 
blages. Achomosphaera sagena is known to have a basal occurrence in the Vraconian (Davey and Verdier, 1971, 1973), and it ranges into the Cenomanian (Davey, 1969; Foucher, 1980; Below, 1984). Based on this, a latest Albian (Vraconian) age is assigned to Samples 101-627B-47X-5, 50-52 cm, through 101627B-46X-5, 50-52 cm.

Samples 101-627B-43X-6, 50-52 cm, through 101-627B-39X-2, $50-52 \mathrm{~cm}$ : problems exist in determining the exact position of the Albian/Cenomanian boundary. A comparison of dinoflagellate-cyst assemblages from well-dated Cenomanian onshore sections (including the type area of the Cenomanian Stage) seems to indicate that a peak abundance of Epelidosphaera spinosa, recorded in lower Cenomanian sediments, may characterize the Cenomanian (Fauconnier, 1983; Foucher, 1979, 1980). In Hole 627B, Epelidosphaeridia spinosa first occurs in Sample 101627B-43X-6, 50-52 cm, in association with Pterodinium cingulatum ssp. cingulatum and Leberidocysta chlamydata. Epelidosphaeridia spinosa is abundant from Samples 101-627B-41X-6, $50-52 \mathrm{~cm}$, through $101-627 \mathrm{~B}-41 \mathrm{X}-3,50-52 \mathrm{~cm}$. On the Scotian Shelf and on the Grand Banks, Epelidosphaeridia spinosa is abundant in the Cleistophaeridium polypes assemblage zone, which is Cenomanian in age (Bujak and Williams, 1978). Below (1984) used the abundance of Epelidosphaeridia spinosa, following Williams (1978), to suggest that samples in DSDP Holes 545 and 547A from the Mazagan Plateau area are no younger than earliest Cenomanian. From the above stratigraphical discussion, one may conclude that Sample 101-627B-43X-6, 50$52 \mathrm{~cm}$, is early Cenomanian in age. Only two species of early Cenomanian age first appear in Samples 101-627B-43X-6, 50$52 \mathrm{~cm}$, through 101-627B-39X-2, 50-52 cm. These are Florentinia clavigera and Kleithriasphaeridium loffrense.

Samples 101-627B-38X-4, 50-52 cm, and 101-627B-38X-3, 50-52 cm: many other species also occur in the dinoflagellatecyst assemblages, including Aldorfia deflandrei, Angustidinium acribes, Dinogymnium microgranulosum, Florentinia deanei, Heterosphaeridium? heteracanthum, Hystrichostrogylon membraniphorum, Senoniasphaera cf. rotundata, and Forma B. Senoniasphaera $\mathrm{cf}$. rotundata has its basal occurrence in the middle Cenomanian in the type area of the Cenomanian Stage (Fauconnier, 1983). The oldest known occurrence of species of the genus Dinogymnium is in the Cenomanian of England (Davey, 1969), France (Azéma et al., 1981), Gabon (Boltenhagen, 1977), and at DSDP Sites 101 (Habib, 1972) and 105 (Habib and Knapp, 1982) in the Bahamas. In Sample 101-627B-38X-4, 50$52 \mathrm{~cm}$, Senoniasphaera $\mathrm{cf}$. rotundata and Dinogymnium microgranulatum are associated with Epelidosphaeridia spinosa and Litosphaeridium siphoniphorum ssp. siphoniphorum. The youngest occurrence of the last two species is in the late Cenomanian (Foucher, 1979) or early Turonian (Bujak and Williams, 1978; Williams and Bujak, 1985). The stratigraphical occurrences discussed above suggest a middle Cenomanian age for Samples 101-627B-38X-4, 50-52 cm, and 101-627B-38X-3, 50-52 cm.

Samples 101-627B-38X-2, 50-52 cm, and 101-627B-38X-1, 50-52 cm: in both samples only one species, Hystrichostrogylon membraniphorum, is additional. A middle Cenomanian age is proposed for this interval.

\section{Unit III (Cores 101-627B-34X through 101-627B-27X; 76 m)}

Three samples were collected in chalks and calcareous-ooze sediments; all are barren (Samples 101-627B-34X-3, 50-52 cm, 101-627B-33X-2, 50-52 cm, and 101-627B-29X-2, 50-52 cm).

\section{Paleoenvironment}

\section{Unit VI (Cores 101-627B-60X through 101-627B-50X; $68 \mathrm{~m}$ )}

The carbonate-platform sediments consist of dolostones and gypsum with minor limestones that were deposited in a restricted shallow-water environment. Twenty-two species were recorded from this unit. Dinoflagellate-cyst assemblages are weakly dominated by Forma A. The lower sample collected from the carbonate platform, Section 101-627B-57X, CC, yields Cepadinium sp. BAHA. Sediments of this sample consist of gypsum with minor dolostone. This morphotype was not observed in sediments of the underlying samples, which consist of dolostone. Cepadinium sp. BAHA appears to be restricted to gypsum sediments.

\section{Unit $V$ (Cores 101-627B-49X through 101-627B-37X; $124 \mathrm{~m}$ )}

The transition between the carbonate platform and the overlying strata appears to be abrupt. The sediments directly overlying the carbonate consist of marls having terrigenous components. Shipboard scientists interpreted Unit V as having been deposited in a shelf environment.

Few specimens in weakly diversified populations $(22,14$ morphotypes) were recorded in Core 101-627B-49X. The dinoflagellate-cyst assemblages are more diverse from Core 101-627B-47X $(23,31$ morphotypes) and contain numerous individual specimens. Forma A is abundant in Sample 101-627B-47X-5, 50-52 $\mathrm{cm}$. From Samples 101-627B-43X-6 50-52 cm, through 101$627 \mathrm{~B}-39 \mathrm{X}-2,50-52 \mathrm{~cm}$, the dinocyst populations commonly are dominated by abundant species. These include Cribroperidinium intricatum (Sample 101-627B-43X-6, 50-52 cm), Cyclonephelium chabaca (Sample 101-627B-41X-6, 50-52 cm), Epelidosphaeridia spinosa and Subtilisphaera? habibi n. sp. (Sample 101-627B-41X-6, 50-52 cm). From Samples 101-627B-41X-3, $50-52 \mathrm{~cm}$, through 101-627B-39X-2, $50-52 \mathrm{~cm}$, dinoflagellatecyst assemblages contain fewer individual specimens than in underlying samples, and populations are dominated by Subtilisphaera? habibi. In Sections 101-627B-38X-4 and 101-627B$38 \mathrm{X}-3$, the dinoflagellate-cyst populations are diverse $(35$ morphotypes) and contain numerous individual specimens. Despite some assemblages containing few individual specimens and, correlatively, few species (Wall et al., 1977), the trend of species diversity of the dinoflagellate-cyst assemblages is an increase from Cores 101-627B-49X through 101-627B-38X. Most species of genus Florentinia appear to be restricted to Hole 627B (see taxa list, this chapter).

\section{Unit III (Cores 101-627B-34X through 101-627B-27X; 76 m)}

No dinoflagellate-cyst assemblages are recorded from sediments of the oceanic plateau.

\section{HOLE 635B, NORTHEAST PROVIDENCE CHANNEL}

Hole 635B was drilled in the thalweg of the Northeast Providence Channel. The 118-m-thick section ranges in age from late Albian to Quaternary. Ten samples were collected from the Cretaceous interval of lithologic Unit III $(57 \mathrm{~m})$ between Cores 101635B-14R and 101-635B-8R. Unit III was divided into Subunits IIIB and IIIA (Austin, Schlager, et al., 1986). Shipboard paleontologists dated Sections 101-635B-14R through 101-635B-13R-3 as early late Albian to early Vraconian, and Section 101-635B13R-2 to Core 101-635B-8R as Vraconian, using planktonic foraminifers. Calcareous nannofossils suggest a late early through early late Albian age for Sections 101-635B-14R, CC through 101-635B-13R-2, a latest Albian or Cenomanian age for Sample 101-635B-12R-1, $110 \mathrm{~cm}$, and a latest Albian through middle Cenomanian age for Cores 101-635B-12R-1 through 101-635B-8R.

\section{Biostratigraphy}

The distribution of the 65 dinoflagellate-cyst taxa found in these 10 samples is tabulated in Figure 3. Full citations for all taxa are given in the "Taxonomy" section (this chapter). 


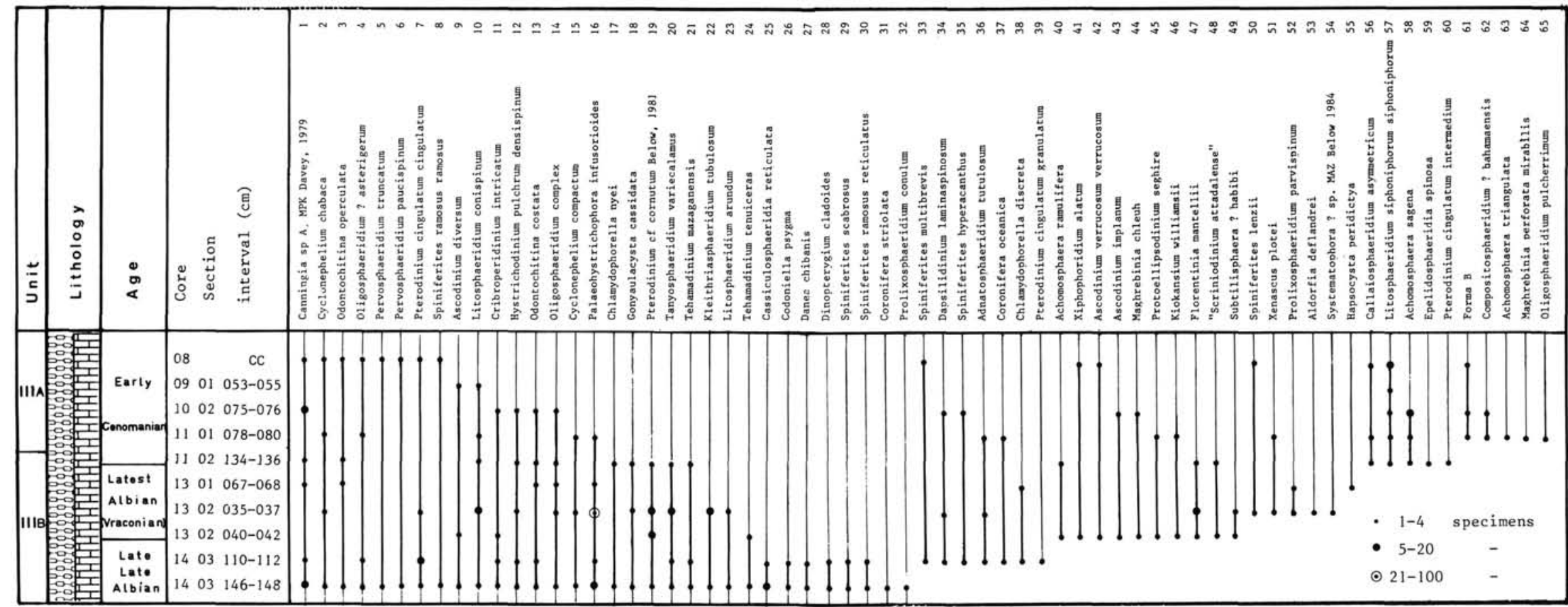

Figure 3. Distribution of dinoflagellate cysts in the mid-Cretaceous of Hole 635B. 
Subunit IIIB (Core 101-635B-14R through Sample $101-635 B-11 R-2,40 \mathrm{~cm} ; 26 \mathrm{~m}$ )

The sediments consist of two debris flows (Samples 101-635B$13 \mathrm{R}-2,120 \mathrm{~cm}$, through 101-635B-12R-2, $35 \mathrm{~cm}$, and Samples 101-635B-12R-2, $25 \mathrm{~cm}$, through 101-635B-11R-2, $40 \mathrm{~cm}$ ), separated from one another by a cyclic chalky limestone.

Sample 101-635B-14R-3, 146-148 cm, and Sample 101-635B$14 \mathrm{R}-3,110-112 \mathrm{~cm}: 39$ species were identified in these two samples from the Northeast Providence Channel area. The dinocyst assemblages are diversified and show similarities to late Albian assemblages described from England, France, and offshore of Northwest Africa. Species common to all four areas are Cyclonephelium chabaca, Cyclonephelium compactum, Litosphaeridium conispinum, Odontochitina costata, Palaeohystrichophora infusorioides, Pterodinium cf. cornutum, and Tehamadinium mazaganensis. The first stratigraphic occurrence of Tehamadinium mazaganensis (=Occisucysta mazaganensis) was recorded in the late Albian near the Vraconian boundary of Hole 545 of offshore Northwest Africa (Below, 1984; Leckie, 1984). Pterodinium $\mathrm{cf}$. cornutum was recorded from the Cenomanian of Morocco (Below, 1981). A late late Albian age is proposed for Samples 101-635B-14R-3, 146-148 cm, and 101-35B-14R-3, 110-112 $\mathrm{cm}$.

Samples 101-635B-13R-2, 40-42 cm, 101-635B-13R-2, 35-37 $\mathrm{cm}$, and 101-635B-13R-1, 67-68 cm: 15 species have their basal occurrence in Section 101-635B-13R-2. Those of stratigraphic interest include Ascodinium verrucosum ssp. verrucosum, Maghrebinia chleuh, and Aldorfia deflandrei. The first stratigraphic occurrences of Ascodinium verrucosum ssp. verrucosum and Aldorfia deflandrei are well known in the Vraconian. These two species range into the Cenomanian (Williams and Bujak, 1985). Ascodinium verrucosum ssp. verrucosum is associated with Maghrebinia chleuh in the Vraconian of the Mazagan Plateau (Below, 1984; Leckie, 1984). Systematophora? sp. MAZ, recorded from the Vraconian of Hole 545 (Below, 1984), was observed in Sample 101-627B-13R-2, 35-37 cm. In Sample 101635B-13R-1, 67-68 cm, only one additional species, Hapsocysta peridyctia, was observed. No reworked species were observed in samples from the lower debris flow. A latest Albian (Vraconian) age is suggested for these three samples from Core 101-635B-13R.

Sample 101-635B-11R-2, 134-136 cm: most of the dinocysts recorded are characteristic of Vraconian-Cenomanian assemblages. Any reworked species were observed in the sample from the upper debris flow. Two morphotypes of stratigraphic interest are Achomosphaera sagena and Epelidosphaeridia spinosa. Achomosphaera sagena is common in the Cenomanian of England (Davey and Williams, 1966a), France (Foucher, 1979), and off the shore of Northwest Africa (Below, 1984). Epelidosphaeridia spinosa was used in Hole 627B to delineate the early Cenomanian; this assignment is based on comparison with a similar peak offshore of southeastern Canada, the Scotian Shelf, and on the Grand Banks (Bujak and Williams, 1978). Peak abundances of Epelidosphaeridia spinosa were not observed in Hole 635B. The occurrence of this species in Sample 101-635B-11R-2, $134-136 \mathrm{~cm}$, suggests an eárly Cenomanian age at this level, although problems exist in assigning this age, which may result from the rare occurrence of Epelidosphaeridia spinosa.

\section{Subunit IIIA (Sample 101-635B-11R-2, $40 \mathrm{~cm}$, through Core 101-635B-8R; $30.5 \mathrm{~m}$ )}

Sediments consist of argillaceous chalk and limestone alternating with dark organic-rich carbonate.

Sample 101-635B-11R-1, 78-80 cm: Compositosphaeridium? bahamaensis and Forma B are found in this sample. In Hole 627B, Forma B has its first occurrence in Sample 101-627B$38 \mathrm{R}-4,50-52 \mathrm{~cm}$, which is dated as middle Cenomanian; this age assignment is based on the occurrence of Senoniasphaera cf. rotundata and Dinogymnium microgranulatum. In Hole
$635 \mathrm{~B}$, these latter species are not recorded. The basal stratigraphic occurrence of Forma B does not seem synchronous in Holes 627B and 635B. An early Cenomanian age might be expected for Sample 101-627B-11R-1, 78-80 cm.

Samples 101-635B-9R-1, 53-55 cm, and 101-635B-8R, CC: no additional species appear in the overlying samples. Therefore, these samples are probably of early Cenomanian age.

\section{Paleoenvironment}

\section{Unit III (Cores 101-635B-14R through 101-635B-8R; $56.7 \mathrm{~m}$ )}

Based on its lithology and particularly on its benthic-foraminifer assemblage, shipboard scientists interpreted Unit III as having been deposited in a bathyal environment (Austin, Schlager, et al., 1986). However, the chalky limestone (Section 101635B-14R, CC) may represent a shallow oceanic environment on the basis of the calcareous nannofossils.

Dinoflagellate-cyst populations from Core 101-635B-14R are relatively diverse (32 morphotypes). Section 101-635B-8R, CC indicates that the assemblage is poorly diversified and contains few individual specimens. Species diversity progressively decreases from Cores 101-635B-14R through 101-635B-8R. Species represented by abundant specimens were rarely observed throughout the section, except for Palaeohystrichophora infusorioides from Sample 101-635B-13R-2, 35-37 cm. Pterodinium appears to be restricted to Hole 635B.

\section{CONCLUSIONS}

\section{Biostratigraphy}

Dinoflagellate-cyst biostratigraphy supports shipboard biostratigraphic results. In summary, age assignments are as follows.

\section{Hole $627 \mathrm{~B}$}

Unit VI: late Albian, Sections 101-627B-57X, CC (535.8 mbsf) through 101-627B-54X, CC (467.8 mbsf).

Unit V: latest Albian (Vraconian), Samples 101-627B-49X-1, 29-31 cm (458.5 mbsf) through 101-627B-46X-5, 50-52 cm (436 mbsf). Early Cenomanian, Samples 101-627B-43X-6, 50-52 cm (409.5 mbsf) through 101-627B-39X-2, 50-52 cm (365.1 mbsf). Middle Cenomanian, Samples 101-627B-38X-4, 50-52 cm (358.5 mbsf) through 101-627B-38X-1, 50-52 cm (324.7 mbsf).

Unit IV: not studied.

Unit III: samples barren, Samples 101-627B-34X-3, 50-52 cm (328.5 mbsf), 101-627B-33X-2, 50-52 cm (298 mbsf), and 101627B-29X-2, 50-52 cm (269.5 mbsf).

Drowning of the carbonate platform started in the latest $\mathrm{Al}$ bian (Vraconian).

\section{Hole $635 B$}

Subunit IIIB: late late Albian, Samples 101-635B-14R-3, 146$148 \mathrm{~cm}$ (118.1 mbsf) through 101-635B-14R-3, 110-112 cm (117.8 mbsf). Latest Albian (Vraconian), Samples 101-635B-13R-2, 40$42 \mathrm{~cm}$ (110.2 mbsf) through 101-635B-13R-1, 67-68 cm (108.9 mbsf). Early Cenomanian, Sample 101-635B-11R-2, 134-136 cm (92.4 mbsf).

Subunit IIIA: early Cenomanian, Sample 101-635B-11R-1, $78-80 \mathrm{~cm}$ (90.3 mbsf) through Section 101-635B-8R, CC (70.6 mbsf).

Although some Unit III rocks (Hole 635B) resemble the Cenomanian marls (Unit V) from Hole 627B, Unit III is older than Unit V.

\section{Paleoenvironment}

\section{Hole $627 B$}

The morphotype Cepadinium sp. BAHA appears to be restricted to the gypsum sediments from the inner part of the ne- 
ritic realm in Unit VI. Species dominances are recorded for sediments from the carbonate platform (Unit VI) and from the marls with terrigenous components (Unit V). An increase in species diversity is recorded from Unit VI to Unit V. In recent marine sediments, the trend of the species diversity indicates an increase from inner to outer parts of the neritic realm and a decrease from neritic to oceanic realms (Wall et al., 1977; Harland, 1983). Major dominances to monospecific assemblages are recorded in the inner part of the neritic realm (Goodman, 1979; Châteauneuf, 1980). These observations suggest that the dinoflagellate-cyst assemblages recorded the deepening of the carbonate platform. Drowning started in the latest Albian (Vraconian) and continued into the middle Cenomanian. The site changed from inner to intermediate or outer(?) parts of the neritic realm. These results support the "megabank" hypothesis (Sheridan et al., 1981). No dinoflagellate-cyst assemblages are recorded from sediments of the oceanic plateau.

\section{Hole 635B}

Significant dominances were not observed in samples from Hole $635 \mathrm{~B}$; the diversity of species progressively decreased throughout the section studied. The dinoflagellate-cyst assemblages appear to indicate a deepening of the area around Hole $635 \mathrm{~B}$ during the late late Albian through the early Cenomanian.

\section{Comparison}

Dinoflagellate-cyst assemblages from Holes 627B and 635B show some differences in composition. Although most species are common to both holes, their relative abundances differ. A succession of species dominances was recorded from Hole 627B. Such significant dominances were not observed in Hole 635B. These observations suggest that Hole $635 \mathrm{~B}$ was located in a deeper environment than Hole 627B.

Differences in the assemblages among sites studied by Habib (1972, 1978), DSDP Sites 99, 100, 101, 105, 387, and 391, and Holes 627B and 635B, may be caused by environmental control. The assemblages found in this study most closely resemble those described from the Mazagan Plateau, Holes 545 and 547, offshore of Northwest Africa, DSDP Leg 79 (Below, 1984).

\section{TAXONOMY}

This section is divided into two parts. The first part lists (in alphabetical order) all dinoflagellate-cyst taxa encountered in the study, with references to plates and figures as well as number and position on the distribution charts. The numbers in parentheses refer to Holes 627B and $635 \mathrm{~B}$, respectively. A zero indicates that the species does not occur in that particular hole. The second part provides morphological descriptions of new species and comments about other species. Gonyaulacoid morphotypes are described using the Taylor-Evitt system (Evitt, 1985) and Helenes' arrangement (Helenes, 1986), and the peridinoid morphotypes are described according to the Kofoid system. The systematic section is arranged alphabetically according to genus.

New species are housed in the Centre Scientifique, G. Deflandre, of the Museum of Natural History in Paris, France.

\section{Taxa List for Dinoflagellate Cysts}

Achomosphaera ramulifera (Deflandre, 1937) Evitt, 1963; Plate 1, Fig. 1. $(29-40)$

Achomosphaera sagena Davey and Williams, 1966a; Plate 1, Fig. 2. (40-58)

Achomosphaera triangulata (Gerlach, 1961) Davey and Williams, 1969. (28-63)

Adnatosphaeridium tutulosum (Cookson and Eisenack, 1960) Morgan, 1980; Plate 1, Fig. 3. (0-36)

Aldorfia deflandrei (Clarke and Verdier, 1967) Stover and Evitt, 1978; Plate 1, Fig. 4. (58-53)

Angustidinium acribes (Davey and Verdier, 1971) Goodman and Evitt, 1981; Plate 1, Fig. 5. (66-0)

Ascodinium diversum (Davey, 1979b) Helenes, 1983; Plate 1, Fig. 6. (0-9) Ascodinium implanum (Davey, 1979b) Helenes, 1983; Plate 1, Fig. 7. $(0-43)$
Ascodinium verrucosum ssp. verrucosum Cookson and Hughes, 1964; Plate 1, Fig. 8. (0-42)

Callaiosphaeridium asymmetricum (Deflandre and Courteville, 1939) Davey and Williams, 1966b. (41-56)

Canningia sp. A. MPK sensu Davey, 1979b, Plate 3, Fig. 4; Plate 1, Fig. 9. (0-1)

Cassiculosphaeridia reticulata Davey, 1969; Plate 1, Fig. 10. (60-25)

Cepadinium? sp. BAHA; Plate 1, Fig. 11. (22-0)

Chlamydophorella discreta Clarke and Verdier, 1967; Plate 1, Fig. 12. (30-38)

Chlamydophorella nyei Cookson and Eisenack, 1958; Plate 1, Fig. 13. (15-17)

Codoniella psygma Davey, 1979b; Plate 1, Fig. 14. (0-26)

Cometodinium? whitei (Deflandre and Courteville, 1939) Stover and Evitt, 1978. (16-0)

Compositosphaeridium? bahamaensis n. sp.; Plate 2, Figs. 1, 2. (23-62)

Coronifera oceanica Cookson and Eisenack, 1958. (11-37)

Coronifera striolata (Deflandre, 1937) Stover and Evitt, 1978; Plate 2, Fig. 3. (42-31)

Cribroperidinium intricatum Davey, 1969. (38-11)

Cyclonephelium chabaca Below, 1981; Plate 2, Fig. 4. (24-2)

Cyclonephelium compactum Deflandre and Cookson, 1955; Plate 2, Fig. 5. (51-15)

Cyclonephelium distinctum ssp. distinctum Deflandre and Cookson, 1955; Plate 2, Fig. 6. (12-0)

Cyclonephelium distinctum ssp. longispinatum Davey, 1978. (31-0)

Cyclonephelium hystrix (Eisenack, 1958) Davey, 1978; Plate 2, Fig. 7. (44-0)

Cyclonephelium paucispinum Davey, 1969. (19-0)

Danea chibanis Below, 1981; Plate 2, Fig. 8. (0-27)

Dapsilidinium duma (Below, 1982) Lentin and Williams, 1985. (46-0)

Dapsilidinium laminaspinosum (Davey and Williams, 1966b) Lentin and Williams, 1981; Plate 2, Fig. 9. (35-34)

Dinogymnium microgranulosum Clarke and Verdier, 1967; Plate 2, Fig. 10. $(61-0)$

Dinopterygium cladoides Deflandre, 1935. (9-28)

Epelidosphaeridia spinosa (Cookson and Hughes, 1964) Davey, 1969a; Plate 2, Fig. 11. (53-59)

Florentinia clavigera (Deflandre, 1937) Davey and Verdier, 1973; Plate 3, Fig. 1. (56-0)

Florentinia deanei Davey and Williams, 1966b) Davey and Verdier, 1973; Plate 3, Fig. 2. (65-0)

Florentinia laciniata ssp. laciniata Davey and Verdier, 1973. (25-0)

Florentinia mantellii (Davey and Williams, 1966b) Davey and Verdier, 1973; Plate 3, Fig. 3. (32-47)

Florentinia radiculata (Davey and Williams, 1966b) Davey and Verdier, 1973; Plate 3, Fig. 4. (50-0)

Florentinia resex Davey and Verdier, 1976. (33-0)

Gonyaulacysta cassidata (Eisenack and Cookson, 1960) Sarjeant, 1966. (0-18)

Hapsocysta peridictya (Eisenack and Cookson, 1960) Davey, 1979b. (055)

Heterosphaeridium? heteracanthum (Deflandre and Cookson, 1955) Eisenack and Kjellström, 1971; Plate 3, Fig. 5. (59-0)

Hystrichodinium pulchrum ssp. densispinum (Deflandre, 1936) Lentin and Williams, 1973. (52-12)

Hystrichosphaeridium bowerbankii Davey and Williams, 1966b. (36-0)

Hystrichostrogylon membraniphorum Agelopoulos, 1964. (67-0)

Kiokansium williamsii Singh, 1983; Plate 3, Fig. 6. (21-46)

Kleithriasphaeridium loffrense Davey and Verdier, 1976. (57-0)

Kleithriasphaeridium tubulosum (Cookson and Eisenack, 1969) Stover and Evitt, 1978. (0-22)

Leberidocysta chlamydata (Cookson and Eisenack, 1962) Stover and Evitt, 1978. (55-0)

Litosphaeridium arundum (Eisenack and Cookson, 1960) Davey, 1979b; Plate 3, Fig. 7. (47-23)

Litosphaeridium conispinum Davey and Verdier, 1973; Plate 3, Fig. 8. $(0-10)$

Litosphaeridium siphoniphorum ssp. siphoniphorum (Cookson and Eisenack, 1958) Davey and Williams, 1966b; Plate 3, Fig. 9. (39-57)

Litosphaeridium sp. BAHA; Plate 3, Fig. 10. (48-0)

Maghrebinia breviornata n. sp.; Plate 3, Figs. 11, 12; Plate 5, Fig. 10; Text-fig. 4. (43-0)

Maghrebinia chleuh Below, 1981; Plate 3, Fig. 13. (26-44)

Maghrebinia perforata ssp. mirabilis Below, 1984; Plate 3, Fig. 14. (37-64) 
Maghrebinia perforata ssp. perforata (Clarke and Verdier, 1967) Below 1981; Plate 3, Fig. 15. (45-0)

Odontochitina costata Alberti, 1961. (1-13)

Odontochitina operculata (O. Wetzel, 1933a) Deflandre and Cookson, 1955. (0-3)

Oligosphaeridium? asterigerum (Gocht, 1959) Davey and Williams, 1969; Plate 4, Fig. 1. (17-4)

Oligosphaeridium complex (White, 1842) Davey and Williams, 1966b. (2-14)

Oligosphaeridium pulcherrimum (Deflandre and Cookson, 1955) Davey and Williams, 1966b; Plate 4, Fig. 2. (18-65)

Palaeohystrichophora infusorioides Deflandre, 1935; Plate 4, Fig. 3. (016)

Pervosphaeridium paucispinum (Eisenack and Cookson, 1960) Jan du Chêne et al., 1986a; Plate 4, Fig. 4. (14-6)

Pervosphaeridium truncatum (Davey, 1969) Below, 1982, emend.; Plate 4, Figs. 5, 6, holotype; Text-fig. 5. (3-5)

Prolixosphaeridium conulum Davey, 1969. (34-32)

Prolixosphaeridium parvispinum (Deflandre, 1937) Davey et al., 1969. (0-52)

Protoellipsodinium seghire Below, 1981; Plate 4, Fig. 7. (0-45)

Pterodinium cingulatum ssp. cingulatum (O. Wetzel, 1933b) Below, 1981; Plate 4, Fig. 8. (54-7)

Pterodinium cingulatum ssp. granulatum (Clarke and Verdier, 1967) Lentin and Williams, 1981. (0-39)

Pterodinium cingulatum ssp. intermedium (Cookson and Eisenack, 1974) Lentin and Williams, 1981; Plate 4, Fig. 9. (0-60)

Pterodinium cf. cornutum Cookson and Eisenack, 1962 sensu Below, 1981; Plate 4, Fig. 10. (0-19)

"Scriniodinium attadalense" (Cookson and Eisenack, 1958) Eisenack, 1967, sensu Habib, 1975, Plate 2, Fig. 8; see also Hochuli and Kelts, 1980, Plate 8, Figs. 7, 8. (0-48)

Scriniodinium? cf. campanula Gocht, 1959; Plate 4, Fig. 11. (49-0)

Senoniasphaera cf. rotundata Clarke and Verdier, 1967; Plate 4, Fig. 12. $(62-0)$

Spiniferites hyperacanthus (Deflandre and Cookson, 1955) Cookson and Eisenack, 1974. (0-35)

Spiniferites lenzii Below, 1982; Plate 4, Fig. 13. (0-50)

Spiniferites multibrevis (Davey and Williams, 1966a) Below, 1982; (4-33)

Spiniferites ramosus ssp. ramosus (Ehrenberg, 1838) Loeblich and Loeblich, 1966. (5-8)

Spiniferites ramosus ssp. reticulatus (Davey and Williams, 1966a) Lentin and Williams, 1973. (0-30)

Spiniferites scabrosus (Clarke and Verdier, 1967) Lentin and Williams, 1975. (0-29)

Spiniferites cf. wetzelii (Deflandre, 1937) Sarjeant, 1970; Plate 5, Fig. 1. (63-0)

Subtilisphaera? habibi n. sp.; Plate 5, Figs. 2, 3, 12; Text-fig. 6. (6-49)

Systematophora? sp. MAZ. sensu Below, 1984; Plate 5, Fig. 4. (0-54)

Tanyosphaeridium variecalamus Davey and Williams, 1966b; Plate 5, Fig. 5. $(27-20)$

Tehamadinium mazaganensis (Below, 1984) Jan du Chêne et al., 1986b; Plate 5, Fig. 6. (0-21)

Tehamadinium tenuiceras (Eisenack, 1958) Jan du Chêne et al., 1986b; Plate 5, Fig. 7. (0-24)

Trichodinium castanea (Deflandre, 1935) Clarke and Verdier, 1967. (10-0)

Xenascus plotei Below, 1981. (7-51)

Xiphophoridium alatum (Cookson and Eisenack, 1962) Sarjeant, 1966. (8-41)

Forma A, Plate 5, Figs. 8, 11; Text-fig. 7. (20-0)

Forma B, Plate 5, Fig. 9. (64-61)

\section{Descriptions}

Class DINOPHYCEAE Fritsch, 1929

Order PERIDINIALES Haeckel, 1894

Genus CEPADINIUM Duxbury, 1983

Type species. Cepadinium variabile Duxbury, 1983, pp. 58, 60; Plate 9, Figs. 1, 4, 8; Text-figs. 27, 28.

\section{Cepadinium? sp. BAHA}

(Plate 1, Fig. 11)

Description. Proximocavate peridinoid dinoflagellate cyst, dorsoventrally flattened with three horns. The single apical and the left antapical are well developed; the right antapical is reduced. There are three wal layers: the endophragm forms the subspheroidal central body; the periphragm forms the three horns and is connected to the ectophragm by processes. The cyst is cornucavate with respect to the pericoel and irregularly cavate with respect to the ectocoel. The surface of the ectophragm is obscure. Archeopyle not observed.

Dimensions. Total length, $68,64,64 \mu \mathrm{m}$; total breadth, $41,36,36$ $\mu \mathrm{m}$; length of apical horns, $14,14,12 \mu \mathrm{m}$; length of left antapical horns, $10,10,8 \mu \mathrm{m}$; three specimens measured and observed.

Comparison. Three or four body layers usually are present in the genus Cepadinium. Three layers are present in Cepadinium? sp. BAHA, but an ectophragm has been observed. This does not conform to the diagnosis of the genus.

Remarks. BAHA denotes "from Bahamas."

Occurrence. Hole 627B (see Fig. 2, no. 22), Section 101-627B-57X, CC: late Albian.

\section{Genus COMPOSITOSPHAERIDIUM Dodekova, 1974}

Type species. Compositosphaeridium polonicum (Gorka, 1965) (=Hystrichosphaeridium polonicum Gorka, 1965, pp. 306-307; Plate 3, Figs. 5, 6) Erkmen and Sarjeant, 1980, pp. 67-69.

$$
\begin{gathered}
\text { Compositosphaeridium? bahamaensis n. sp. } \\
\text { (Plate 2, Figs. 1, 2) }
\end{gathered}
$$

Derivation of name. Bahamas, location of Hole 627B, Leg 101.

Diagnosis. Proximochorate two-layered dinoflagellate cyst with subspheroidal central body. Smooth endophragm and periphragm appressed between processes. Periphragm with membranous reticulated ridges on the surface of central body. "Polytubular" intratabular processes, whose height is about $30 \%$ of the endocyst diameter. Gonyaulacoid paratabulation; processes represent 4 apicals, 6 precingulars, 6 cingulars, $X$ sulcals, 5-6 postcingulars, ?1 posterior intercalary, 1 antapical. Apical archeopyle, type (4A).

Holotype. Slide 3: TU 43-44; Sample 101-627B-38X-2, 50-52 cm.

Type locality. Hole 627B, Leg 101, offshore Bahamas (east of Florida).

Type biohorizon. Cenomanian. Depth: 355.5 mbsf.

Dimensions. Holotype: central body diameter, $30 \mu \mathrm{m}$; length of processes, 6-9 $\mu \mathrm{m}$; total diameter, $47 \mu \mathrm{m} ; 20$ specimens measured: central body diameter, 33 (31) $28 \mu \mathrm{m}$; length of processes, 12 (9) $6 \mu \mathrm{m}$.

Description. The intratabular processes are "polytubular" and open distally. The number of processes and tubes varies according to the position and size of the paraplates they reflect. The pre- and post-cingular processes are larger than the apical and antapical ones. The cingular processes are narrow mono- or polytubular. All processes are joined proximally by membranous reticulate ridges with irregular meshes. The organization of the processes is difficult to observe when the detachment between the endophragm and periphragm is large.

Comparison. The number of processes is more than one for each paraplate. This does not conform to the diagnosis for the genus. Compositosphaeridium? bahamaensis differs from $C$. bulgaricum and $C$. polonicum in having shorter intratabular processes and well-developed reticulate ridges proximally linking the processes on the central body.

Occurrence. Hole 627B (see Fig. 2, no. 23), Samples 101-627B-49X-1, 29-31 cm, to 101-627B-38X-1, 50-52 cm, latest Albian (Vraconian), middle Cenomanian; Hole 635B (see Fig. 3, no. 62), Samples 101-635B$11 \mathrm{R}-1,78-80 \mathrm{~cm}$, to $101-635 \mathrm{~B}-10 \mathrm{R}-2,75-76 \mathrm{~cm}$, early Cenomanian.

Genus LITOSPHAERIDIUM Davey and Williams, 1966; emend. Davey and Verdier, 1973; emend. Lucas-Clarke, 1984

Type species. Litosphaeridium siphoniphorum (Cookson and Eisenack, 1958) (= Hystrichosphaeridium siphoniphorum Cookson and Eisenack, 1958, p. 44; Plate 11, Figs. 8-10) Davey and Williams, 1966, pp. 80-82, emend. Lucas-Clark, 1984, p. 186.

\section{Litosphaeridium sp. BAHA}

(Plate 3, Fig. 10)

Description. Skolochorate, two-layered dinoflagellate cyst, with subspheroidal central body. Granular endophragm and smooth periphragm appressed between processes. Intratabular, hollow processes with secate or scutellate distal margin. Gonyaulacoid paratabulation, processes represent 4 apicals, 6 precingulars, $X$ cingulars, $X$ sulcals, 6 postcingulars, ?1 posterior intercalary, 1 antapical. Apical archeopyle, type (4A). 
Dimensions. Diameter, $50 \mu \mathrm{m}$; central body diameter, $40 \mu \mathrm{m}$; length of processes, 8-10 $\mu \mathrm{m}$.

Comparison. Litosphaeridium sp. BAHA differs from the other species in having secate or scutellate distal margin processes.

Remarks. Too few specimens are available to formally erect a new species.

Occurrence. Hole 627B (see Fig. 2, no. 48), Sample 101-627B-47X-5, $50-52 \mathrm{~cm}$; latest Albian (Vraconian).

\section{Genus MAGHREBINIA Below, 1981}

Type species. Maghrebinia perforata (Clarke and Verdier, 1967) $(=\mathrm{Di}$ nopterygium perforatum, Clarke and Verdier, 1967, p. 36; Plate 6, Figs. 1-3; Text-fig. 15) Below, 1981, p. 23.

Maghrebinia breviornata $\mathrm{n} . \mathrm{sp}$.

(Plate 3, Figs. 11, 12; Text-fig. 4; Plate 5, Fig. 10) tion.

Derivation of name. Latin brevi, reduced, and ornata, ornamenta-

Synonymy. 1978-?Maduradinium sp. A, Davey, pp. 894-895; Plate 5, Figs. 5, 6.

Diagnosis. Proximate gonyaulacoid dinoflagellate cyst, single-walled with subovoidal ambitus and smooth surface, divided into a small epicyst and large hypocyst. Low granular, penitabular ornamentation. Gonyaulacoid paratabulation with large undifferentiated ventral area: ?2 preapicals, 4 apicals, 1 anterior intercalary $(\mathrm{K}), 6$ precingulars, 6 cingulars, 5 sulcals, 6 postcingulars, ? 1 posterior intercalary, 1 antapical. Apical archeopyle, type (4A), operculum adnate; accessory archeopyle sutures well developed.

Holotype. Slide 1: J49; Sample 101-627B-47X-5, 50-52 cm.

Type locality. Hole 627B, Leg 101, offshore Bahamas (east of Florida).

Type biohorizon. Cenomanian. Depth: 409.5 mbsf.

Dimensions. Holotype: length, $72 \mu \mathrm{m}$; breadth, $64 \mu \mathrm{m} ; 10$ specimens measured: length, 73 (64) $60 \mu \mathrm{m}$, breadth, 73 (70) $66 \mu \mathrm{m}$.

Description. Penitabular ornamentation weakly developed on apical paraplates, strongly expressed on precingular paraplates, and highly developed in antapical area, with intratabular granules on $\mathrm{Z}$ and $\mathrm{Y}$. Cingular paraplates are delineated by penitabular granules on dorsal surface. The granule alignments are weakly developed between IV/V and V/VI paraplates. An additional $\mathrm{K}$ paraplate is present. $\mathrm{A}$ is in contact with ai, $\mathrm{A}$ /ai arrangement. Paraplate 5 is camarate with respect to $\mathrm{K}$. The operculum is adnate. The principal archeopyle suture fails to open following adapical boundaries of the parasulcus and of the precingular paraplates, 2 and 1i. The accessory archeopyle sutures $2 / 3$ and $6 / 1 \mathrm{i}$ are well developed.

Comparison. Maghrebinia breviornata differs from the other species of Maghrebinia in having granular and reduced ornamentation.

Occurrence. Hole 627B (see Fig. 2, no. 43), Sample 101-627B-47X-5, $50-52 \mathrm{~cm}$, to Sample 101-627B-38X-3, 50-52 cm, latest Albian-Vraconian, middle Cenomanian.

\section{Genus PERVOSPHAERIDIUM Yun, 1981}

Type species. Pervosphaeridium pseudhystrichodinium (Deflandre, 1937) (= Hystrichosphaeridium pseudhystrichodinium Deflandre, 1937, p. 73; Plate 15, Figs. 3, 4) Yun, 1981, p. 29.

Pervosphaeridium truncatum (Davey, 1969) Below, 1982 emend. (Plate 4, Fig. 6; Text-fig. 5, holotype; Plate 4, Fig. 5)

Synonymy. 1969-Exochosphaeridium striolatum (Deflandre, 1937) var. truncatum var. nov. Davey, pp. 164-165; Plate 7, Fig. 2.

1982-Pervosphaeridium truncatum (Davey, 1969) Below, p. 27.

Emended diagnosis. Proximochorate, two-layered dinoflagellate cyst with subspheroidal central body and fibrous, lightly pitted periphragm. Processes intratabular, hollow, fibrous with broad bases, blunted distally, slender, some joined proximally. Apical and antapical processes well developed. Gonyaulacoid paratabulation; processes represent 1-?2 preapicals, 4 apicals, 6 precingulars, 6 cingulars, $X$ sulcals, 5-6 postcingulars, ?1 posterior intercalary, 1 antapical. Precingular archeopyle, type $2 \mathrm{P}$ 3-4.

Emended description. The processes are intratabular, with one or more than one for each paraplate. The processes of the post-cingular paraplates (III, IV) may form a penitabular complex, with their broad bases joined proximally. The preapical process is distinctive; the antapical $\mathrm{Y}$ is well developed.

Comparison. $P$. truncatum differs from other species of the genus in having some processes joined proximally. The archeopyle formula of the genus Pervosphaeridium is 2P (Yun, 1981). Below (1981, p. 60) specified that the archeopyle of Pervosphaeridium paucispinum was 2P 3-4. $P$. truncatum and $P$. paucispinum appear to have 2P 3-4 archeopyle formula.

Remarks. We based our emendation on reexamination of the holotype.

Occurrence. Hole 627B (see Fig. 2, no. 3), Section 101-627B-57X, $\mathrm{CC}$ to Sample 101-627B-38X-1, 50-52 cm, late Albian-middle Cenomanian; Hole 635B (see Fig. 3, no. 5), Sample 101-635B-14R-3, 146-148 $\mathrm{cm}$, to Section 101-635B-8R, CC, late late Albian-early Cenomanian.

\section{Genus SUBTILISPHAERA Jain and Millepied, 1973}

Type species. Subtilisphaera senegalensis Jain and Millepied, 1973, pp. 27-28; Plate 3, Figs. 31, 33.

Subtilisphaera? habibi $\mathrm{n} . \mathrm{sp}$.

(Plate 5, Figs. 2, 3, 12; Text-fig. 6)

Derivation of name. In honor of Dr. D. Habib, palynologist.

Diagnosis. Bicavate, peridinoid dinoflagellate cyst, dorsoventrally flattened. Three horns: one apical, one well developed left antapical, and one highly reduced right antapical. Endophragm subspheroidal, slightly granular. Periphragm thin, with short to long flexous intratabular spines and pandasutural bands. Very low parasutural ridges expressed only on periphragm where endophragm and periphragm are appressed. Peridinoid paratabulation: 1-2? $\mathrm{pr}, 4^{\prime}, 3 \mathrm{a}, 7^{\prime \prime}, \mathrm{Xc}, 5^{\prime \prime \prime}, 2^{\prime \prime \prime \prime}, \mathrm{Xs}$, with ortho/hexa-type paratabulation. Endoarcheopyle, 313P, adherent?; periarcheopyle uncertain.

Holotype. Slide 1: N 0 34-35, Sample 101-627B-39X-6, 50-52 cm. ida).

Type locality. Hole 627B, Leg 101, offshore Bahamas (east of Flor-

Type biohorizon. Cenomanian. Depth: $371.1 \mathrm{mbsf}$.

Dimensions. Holotype: length, $64 \mu \mathrm{m}$; breadth, $40 \mu \mathrm{m}$; length of endocyst, $42 \mu \mathrm{m}$; length of apical horn, $12 \mu \mathrm{m}$; length of left antapical horn, $10 \mu \mathrm{m}$; length of spines, $1-2 \mu \mathrm{m} ; 20$ specimens measured: length, 68 (64) $60 \mu \mathrm{m}$; breadth, 44 (40) $38 \mu \mathrm{m}$.

Description. Peridinoid bicavate cyst with well-developed apical and left antapical horns, and truncated right antapical horn. Endophragm granular. Periphragm smooth, with low parasutural ridges present only where the endophragm and periphragm are appressed. Some specimens show only penitabular spines, whereas others have intratabular spines. All have pandasutural bands. 1' paraplate is in contact with the two precingulars 1" and 7 ", and so is the ortho type; $2 \mathrm{a}$ is in contact with $3^{\prime \prime}, 4^{\prime \prime}$ and $5^{\prime \prime}$, and so is the hexa type.

Comparison. Subtilisphaera? habibi is a provisionally accepted species of Subtilisphaera because it has a paratabulation indicated by ornamentation. Parasutural ridges, pandasutural bands, and intratabular spines differentiate Subtilisphaera? habibi from Palaeohystrichophora infusorioides. Pericoels in Subtilisphaera? habibi are more developed than in Chichaouadinium arabicum. The archeopyles of the genera Chichaouadinium (I3P), Luxadinium 3I3P/3I3P, Laciniadinium (3I3P)a, Ginginodinium (3IPa), and Diconodinium (IPa), do not correspond to the archeopyle of Subtilisphaera? habibi.

Remarks. The paratabulation, which is of the ortho/hexa type, the pandasutural bands, and the intratabular spines suggest that Subtilisphaera? habibi may be related to the cyst of the modern freshwater dinoflagellate Pterodinium limbatum. Under the scanning electron microscope no grooves were observed on the inner surface of the endophragm as is found in Pterodinium limbatum. The periarcheopyle of Pterodinium limbatum is (A3I3P)a; that of Subtilisphaera? habibi is uncertain.

Occurrence. Hole 627B (see Fig. 2, no. 6), Section 101-627B-57X, $\mathrm{CC}$ to Sample 101-627B-38X-1, 50-52 cm, late Albian-middle Cenomanian; Hole 635B (see Fig. 3, no. 49), Samples 101-635B-13R-2, 40-42 $\mathrm{cm}$, to 101-635B-13R-2, 35-37 cm, latest Albian (Vraconian).

Forma A

(Plate 5, Figs. 8, 11; Text-fig. 7)

Description. Proximate spheroidal dinoflagellate cyst. Autophragm thin and smooth. Gonyaulacoid paratabulation expressed by very low 

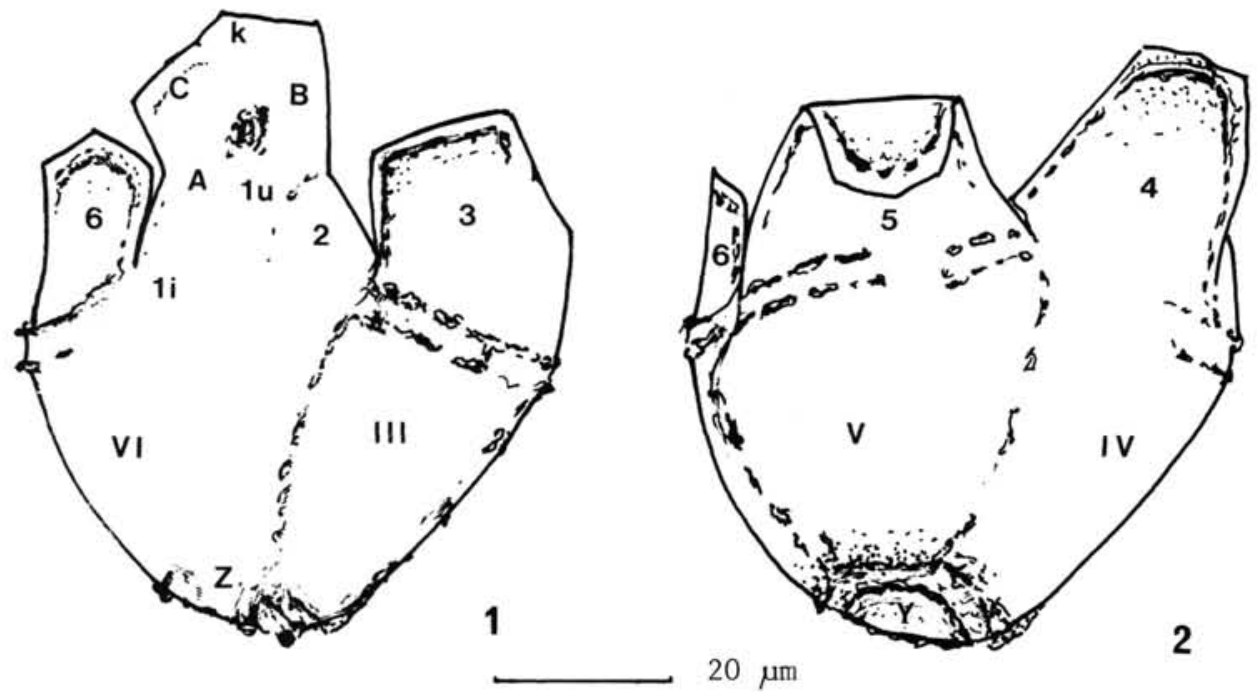

Figure 4. Paratabulation of Maghrebinia breviornata n. sp., according to the Taylor-Evitt system. 1. Ventral face. 2. Dorsal face, interior view.

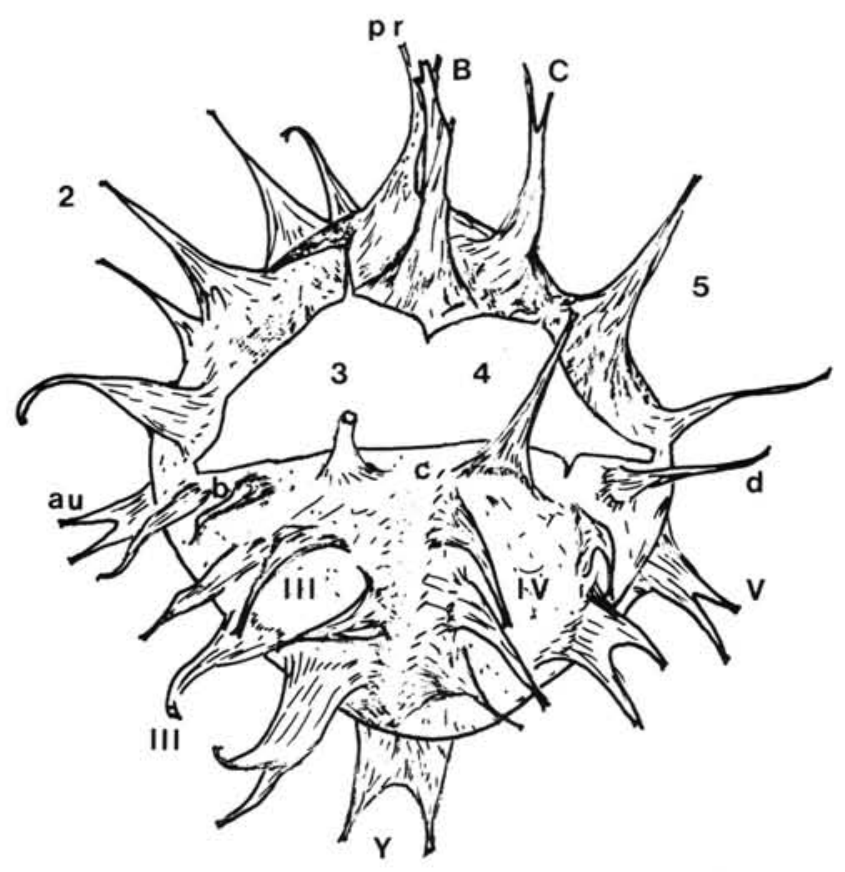

1

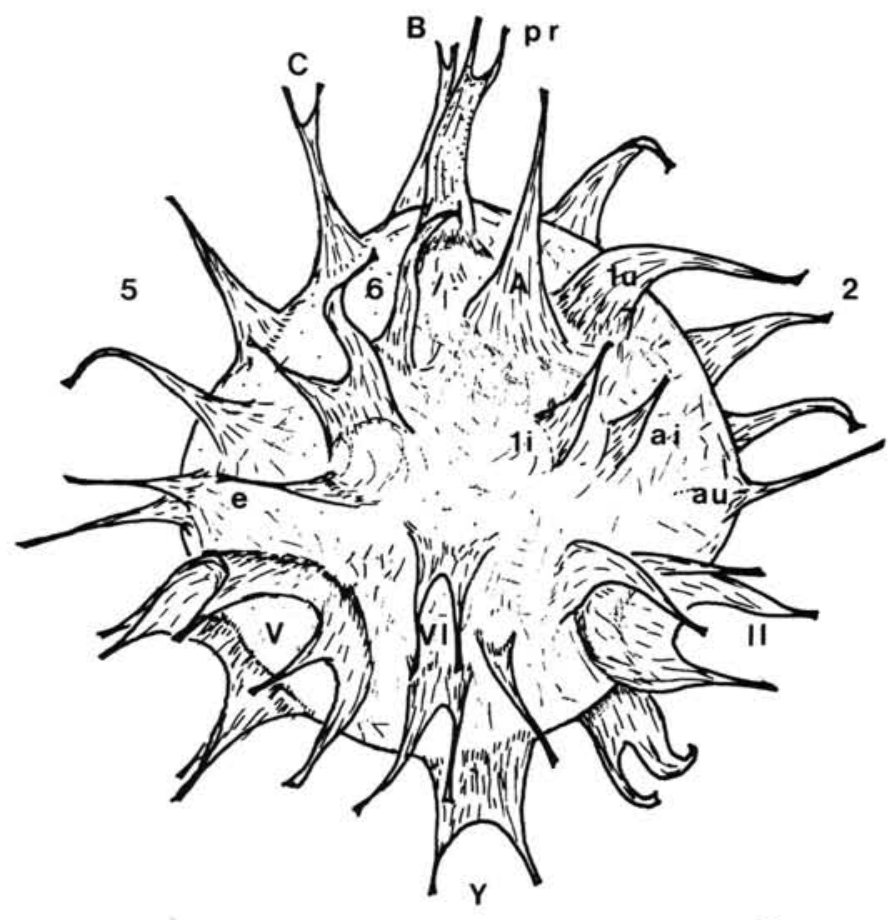

2

Figure 5. Paratabulation of the holotype of Pervosphaeridium truncatum, according to the Taylor-Evitt system. 1. Dorsal face. 2. Ventral face.

ridges with elongated $\mathrm{Z}$ and $\mathrm{X}$, quinqueform hypocyst pattern. Archeopyle uncertain, not observed.

Dimensions. Diameter, 48 to $58 \mu \mathrm{m} ; 20$ specimens measured.

Comparison. Forma A should be attributed to the genera Chytroeisphaeridia (Sarjeant, 1962) Downie and Sarjeant, 1965; emend. Pocock, 1972; emend. Davey, 1979c, in regard to its smooth hyaline unstructured autophragm as seen under the light microscope. Chytroeisphaeridia has a precingular archeopyle, type $\mathrm{P}$; the archeopyle of Forma A is uncertain.

Remarks. Under the light microscope the paratabulation, which is expressed by low ridges, is not visible. The thin, fragile autophragm tears in a random fashion. The delicacy of the wall and the absence of independent indications of paratabulation may contribute to this situation.

Occurrence. Hole 627B (see Fig. 2, no. 20), Section 101-627B-57X, CC to Sample 101-627B-43X-6, 50-52 cm, late Albian-early Cenomanian.

\section{Forma B}

(Plate 5, Fig. 9)

Description. Skolochorate double-walled dinoflagellate cyst, with subspheroidal central body. Endophragm and periphragm appressed between processes. Endophragm slightly granular; periphragm with ridges proximally joining the processes on the central body. Intratabular hol- 

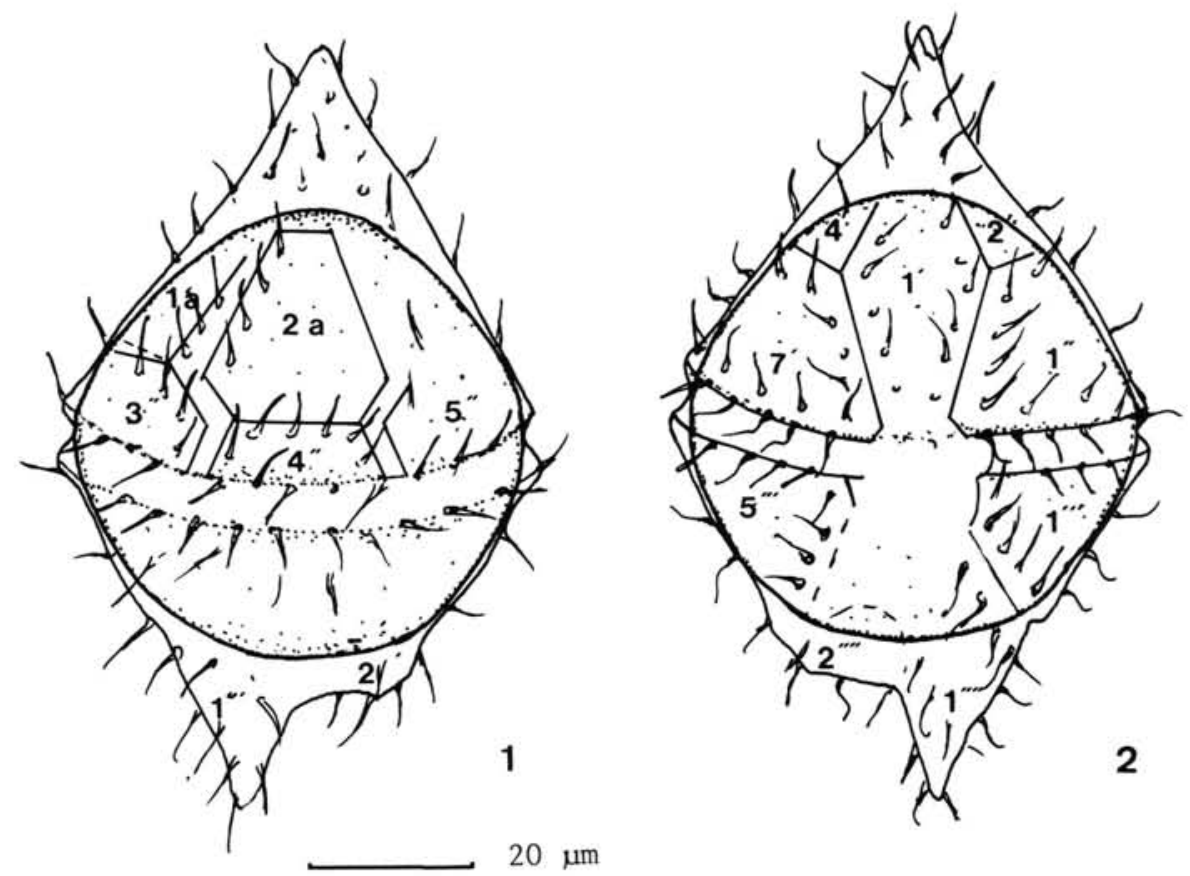

Figure 6. Paratabulation of Subtilisphaera? habibi n. sp., according to the Kofoid system. 1. Dorsal face. 2. Ventral face.

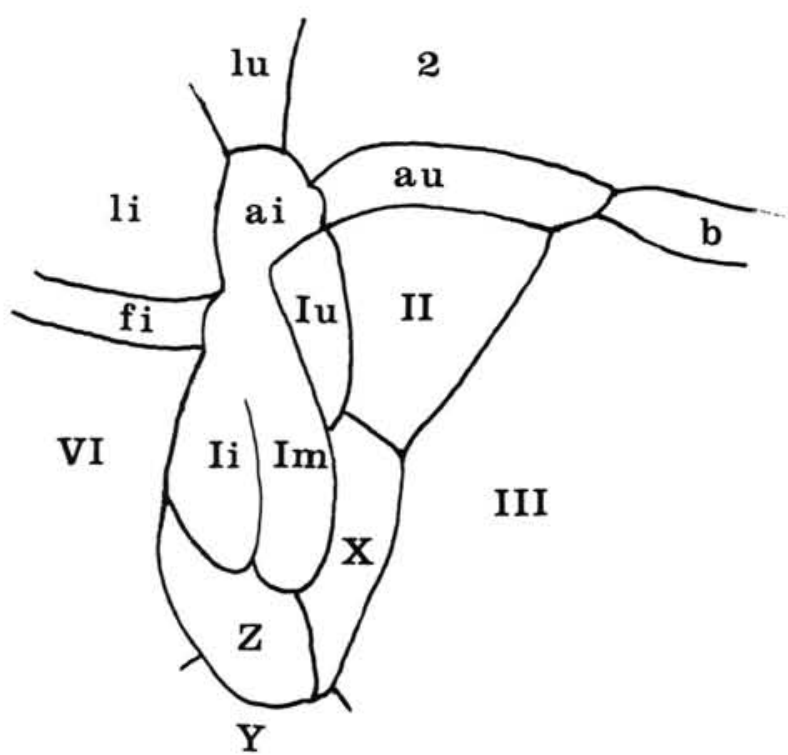

$20 \mu \mathrm{m}$

Figure 7. Paratabulation of the sulcal area of Forma A, according to the Taylor-Evitt system.

low processes distally closed, with ridges and granular proximal bases. Gonyaulacoid paratabulation, processes represent ?1-2 preapicals, 4 apicals, 6 precingulars, $\mathrm{X}$ cingulars, $\mathrm{X}$ sulcals, 5-6 postcingulars, ? 1 posterior intercalary, 1 antapical. Precingular archeopyle, type $2 \mathrm{P}$, formula uncertain.

Dimensions. Breadth included processes $44 \mu \mathrm{m}$.

Comparison. Forma B should be attributed to the genus Pervosphaeridium, Yun, 1981, with respect to the $2 \mathrm{P}$ archeopyle. Forma $\mathrm{B}$ differs from Pervosphaeridium in having one process for each paraplate (more than three for Pervosphaeridium) and striate processes (fibrous for Per- vosphaeridium). Forma B differs from Kleithriasphaeridium in having $2 \mathrm{P}$ archeopyle, rather than $\mathrm{P}$, and processes distally closed.

Remarks. Only 4 specimens, none of which was well preserved or favorably oriented, were observed.

Occurrence. Hole 627B (see Fig. 2, no. 64), Sample 101-627B-38X-4, $50-52 \mathrm{~cm}$, middle Cenomanian. Hole 635B (Fig. 3, no. 61), Sample 101635B-11R-1, 78-80 cm, to Section 101-635B-8R, CC, early Cenomanian.

\section{ACKNOWLEDGMENTS}

I thank the staff of ODP for making material available. I also express my appreciation to Dr. Fourcade, who provided working facilities; U.A. 319 and CNRS "soutien" ODP France for financial support; and the Micropaleontology Laboratory (Miss Codet) for technical support. The help of Drs. W. R. Evitt, G. L. Williams, J. A. Austin, Jr., A. A. Palmer, and W. Schlager, who reviewed the manuscript, is acknowledged with thanks.

\section{REFERENCES}

Agelopoulos, J., 1964. Hystrichostrogylon membraniphorum n. g., n. sp. aus dem Heiligenhafener Kieselton (Eozän). N. Jahrb. Geol. Palaeontol. Monatsh., 15:673-675.

Alberti, G., 1961. Zur Kenntnis mesozoischer und alt-tertiärer Dinoflagellaten und Hystrichosphaerideen von Nord- und Mitteldeutschland sowie einigen anderen europäischen Gebieten. Palaeontographica, 116(A):1-58.

Austin, J. A., Jr., Schlager, W., et al., 1986. Proc. ODP, Init. Repts., 101: College Station, TX (Ocean Drilling Program).

Azéma, C., Fauconnier, D., and Viaud, M. J., 1981. Microfossils from the upper Cretaceous of Vendée (France). Rev. Palaeobot. Palynol., 35:237-281.

Below, R., 1981. Dinoflagellaten-Zysten aus dem oberen Hauterive bis unteren Cenoman Süd-West-Marokkos. Palaeontographica, 176(B): $1-145$.

, 1982. Scolochorate Zysten der Gonyaulacaceae (Dinophyceae) aus der Unterkreide Marokkos. Palaeontographica, 182(B):1-51.

, 1984. Aptian to Cenomanian dinoflagellate cysts from Mazagan Plateau, northwest Africa (Sites 545 and 547, Deep Sea Drilling Project Leg 79). In Hinz, K., Winterer, E. L., et al., Init. Repts. DSDP, 79: Washington (U.S. Govt. Printing Office), 621-649. 
Boltenhagen, E., 1977. Microplancton du Crétacé supérieur du Gabon. Cah. Paleontol.

Brideaux, W. W., and McIntyre, D. J., 1975. Miospores and microplankton from Aptian-Albian rocks along Horton River, District of Mackenzie. Bull. Geol. Surv. Canada, 252:1-85.

Bujak, J. P., and Williams, G. L., 1978. Cretaceous palynostratigraphy of offshore southeastern Canada. Bull. Geol. Surv. Canada, 297: $1-19$.

Châteauneuf, J.-J., 1980. Palynostratigraphie et paléoclimatologie de l'Eocène supérieur et de l'Oligocène du Bassin de Paris. Mem. Bur. Rech. Geol. Min., 116:1-360.

Clarke, R.F.A., and Verdier, J.-P., 1967. An investigation of microplankton assemblages from the Chalk of the Isle of Wight, England. K. Nederl. Akad. Wetensch. Afd. Nat. Eerste Reeks, 24:1-96.

Cookson, I. C., and Eisenack, A., 1958. Microplankton from Australian and New Guinea upper Mesozoic sediments. Proc. R. Soc. Victoria, 70:19-79.

1960. Microplankton from Australian Cretaceous sediments. Micropaleontology, 6:1-18.

1962. Additional microplankton from Australian Cretaceous sediments. Micropaleontology, 8:485-507.

1969. Some microplankton from two bores at Balcatta, Western Australia. J. R. Soc. West. Aust., 52:3-8.

1970. Cretaceous microplankton from the Eucla Basin, Western Australia. Proc. R. Soc. Victoria, 83:137-157.

, 1974. Mikroplankton aus Australischen mesozoischen und tertiären Sedimenten. Palaeontographica, 148(B):44-93.

Cookson, I. C., and Hughes, N. F., 1964. Microplankton from the Cambridge Greensand (mid-Cretaceous). Palaeontology, 7:37-59.

Davey, R. J., 1969. Non-calcareous microplankton from the Cenomanian of England, northern France and North America, Part I. Bull. Br. Mus. Nat. Hist., Geol., 17:1-11.

1970. Non-calcareous microplankton from the Cenomanian of England, northern France and North America, Part II. Bull. Br. Mus. Nat. Hist., Geol., 18:333-397.

1978. Marine Cretaceous palynology of Site 361, DSDP Leg 40, off southwestern Africa. In Bolli, H. M., Ryan, W.B.F., et al., Init. Repts. DSDP, 40: Washington (U.S. Govt. Printing Office), 883-913.

1979a. Two new Early Cretaceous dinocyst species from the northern North Sea. Palaeontology, 22:427-437.

1979b. Marine Apto-Albian palynomorphs from Holes 400A and 402A, IPOD Leg 48, northern Bay of Biscay. In Montadert, L., Roberts, D. G., et al., Init. Repts. DSDP, 48: Washington (U.S. Govt. Printing Office), 547-577.

1979c. A re-appraisal of the genus Chytroeisphaeridia Sarjeant, 1962. Palynology, 3:209-218.

Davey, R. J., Downie, C., Sarjeant, W.A.S., and Williams, G. L., 1969. Generic reallocations. Bull. Br. Mus. Nat. Hist., Geol., Append. to Suppl., 3:15-17.

Davey, R. J., and Verdier J.-P., 1973. An investigation of microplankton assemblages from Albian of the Paris Basin. Verh. K. Nederl. Akad. Wetensch. Afd. Nat. Eerste Reeks, 26:1-58.

1973. An investigation of microplankton assemblages from latest Albian (Vraconian) sediments. Rev. Esp. Micropaleontol., 5: 173-212.

1976. A review of certain non-tabulate Cretaceous hystrichospherid dinocysts. Rev. Palaeobot. Palynol., 22:307-335.

Davey, R. J., and Williams, R. J., 1966a. The genera Hystrichosphaera and Achomosphaera. Bull. Br. Mus. Nat. Hist., Geol., Suppl., 3: 28-52.

1966b. The genus Hystrichosphaeridium and its allies. Bull. Br. Mus. Nat. Hist., Geol., Suppl., 3:53-106.

1969. Generic reallocations. Bull. Br. Mus. Nat. Hist., Geol., Append. to Suppl., 3:4-7.

Deflandre, G., 1935. Considérations biologiques sur les microorganismes d'origine plantonique conservés dans les silex de la craie. Bull. Biol. France Belg., 69:213-244.

1936. Microfossiles des silex crétacés. Première partie. Généralités. Flagellés. Ann. paleontol., 25:151-191.

1937. Microfossiles des silex crétacés. Deuxième partie. Flagellés incertae sedis Hystrichosphaeridés, Sarcodinés. Organismes divers. Ann. paleontol., 26:51-103.
Deflandre, G., and Cookson, I. C., 1955. Fossil microplankton from Australian late Mesozoic and Tertiary sediments. Aust. J. Mar. Freshwater Res., 6:242-313.

Deflandre, G., and Courteville, H., 1939. Note préliminaire sur les microfossiles des silex Crétacés de Cambrésis. Bull. Soc. Fran. Microsc., 8:95-106.

Dodekova, L. 1974. Compositosphaeridium gen. n.-a new genus dinoflagellate cyst. Bull. Acad. Sci., Min. Heavy Ind., Bull. Geol. Inst., Ser. Paleontol., 23:25-30.

Downie, C., and Sarjeant, W.A.S., 1965. Bibliography and index of fossil dinoflagellates and arcritarchs. Geol. Soc. Am. Mem., 94: $1-180$.

Duxbury, S., 1983. A study of dinoflagellate cysts and acritarchs from the lower Greensand (Aptian to lower Albian) of the Isle of Wight, southern England. Palaeontographica, 186(B):18-80.

Ehrenberg, C. G., 1838. Über das Massenverhältnifs der jetzt lebenden Kiesel-Infusorien und Über ein neues Infusorien-Conglomerat als Polirschiefer von Jastraba in Ungarn. Abh. Preuss. Akad. Wiss., 1836:109-135.

Eisenack, A., 1958. Mikroplankton aus dem norddeutschen Apt. $N$. Jahrb. Geol. Palaeontol., Abh., 106:383-422.

1967. Katalog der Fossilen Dinoflagellaten, Hystrichosphaeren und Verwandten Mikrofossilien. Band I: Stuttgart (E. Schweizerbart'sche Verlagsbuchhandlung).

Eisenack, A., and Cookson, I. C., 1960. Microplankton from Australian Lower Cretaceous sediments. Proc. $R$. Soc. Victoria, 72:1-11.

Eisenack, A., and Kjellström, G., 1971. Katalog der Fossilen Dinoflagellaten, Hystrichosphäeren und Verwandten Mikrofossilien. Band II, Dinoflagellaten: Stuttgart (E. Schweizerbart'sche Verlagsbuchhandlung).

Erkmen, U., and Sarjeant, W.A.S., 1980. Dinoflagellate cysts, acritarchs and tasmanitids from the uppermost Callovian of England and Scotland: with a reconsideration of "Xanthidium pilosum" problem. Geobios, 13:45-99.

Evitt, W. R., 1963. A discussion and proposals concerning fossil dinoflagellates, hystrichospheres, and acritarchs, I. Proc. Natl. Acad. Sci., Washington, 49:158-164.

1985. Sporopollenin Dinoflagellate Cysts, Their Morphology and Interpretation: Am. Assoc. Stratigr. Palynol. Found.

Fauconnier, D., 1983. Etude de trois sondages dans la région-type du Cénomanien. La limite Albien-Cénomanien dans la Sarthe (France). Bull. Bur. Rech. Geol. Min., 3:193-234.

Foucher, J.-C., 1979. Distribution stratigraphique des kystes de Dinoflagellés et des Acritarches dans le Crétacé supérieur du bassin de Paris et de l'Europe septentrionale. Palaeontographica, 169(B):78105.

1980. Synthèse biostratigraphique de l'Aptien au Santonien du Boulonnais à partir de sept groupes paléontologiques: Foraminifères, Nannoplancton, Dinoflagellés et Macrofaunes, Zonations micropaléontologiques intégrées dans le cadre du Crétacé boréal nordeuropéen. J. Rev. Micropaleontol., 22:195-321.

1982. Le Turonien de la région-type: Saumurois et Touraine stratigraphie, biozonations, sédimentologie. Bull. Cent. Rech. Explor-Prod. Elf-Aquitaine, 6:119-225.

Gerlach, E., 1961. Mikrofossilien aus dem Oligozän und Miozän Nordwestdeutschlands, unter besonderer Berücksichtigung der Hystrichosphaeren und Dinoflagellaten. N. Jahrb. Geol. Palaeontol., Abh., 112:143-228.

Gocht, H., 1959. Mikroplankton aus dem nordwestdeutschen Neokom (Teil II). Palaeontol. Z., 33:50-89.

Goodman, D. K., 1979. Dinoflagellate "communities" from the lower Eocene Nanjemoy Formation of Maryland, U.S.A. Palynology, 3: 169-190.

Goodman, D. K., and Evitt, W. R., 1981. The dinoflagellate Angustidinium acribes (Davey and Verdier) gen. et comb. nov. from the midCretaceous of the northern California Coast Ranges. Grana, 20: 43-54.

Gorka, H., 1965. Les microfossiles du Jurassique supérieur de Magnuszew (Pologne). Acta Palaeontol. Polonica, 10:291-327.

Habib, D., 1972. Dinoflagellate stratigraphy, Leg 11, Deep Sea Drilling Project. In Hollister, C. D., Ewing, J. I., et al., Init. Repts. DSDP, 11: Washington (U.S. Govt. Printing Office), 367-392. 
1975. Neocomian dinoflagellate zonation in the western North Atlantic. Micropaleontology, 21:373-392.

1977. Comparison of Lower and middle Cretaceous palynostratigraphic zonations in the western North Atlantic. In Swain, F. W. (Ed.), Stratigraphic Micropaleontology of Atlantic Basin and Borderlands. Amsterdam (Elsevier), 44:887-897.

1978. Palynostratigraphy of the Lower Cretaceous section at Deep Sea Drilling Project Site 391, Blake-Bahama Basin, and its correlation in the North Atlantic. In Benson, W. E., Sheridan, R. E., et al., Init. Repts. DSDP, 44: Washington (U.S. Govt. Printing Office), 887-897.

Habib, E., and Knapp, S. D., 1982. Stratigraphic utility of Cretaceous small acritarchs. Micropaleontology, 28:335-371.

Harland, R., 1983. Distribution maps of recent dinoflagellate cysts in bottom sediments from the North Atlantic Ocean and adjacent seas. Palaeontology, 26:321-387.

Helenes, J., 1983. Evaluation of Jurassic-Cretaceous dinoflagellates in the Ascodinium-Ovoidinium complex. Micropaleontology, 29:255266.

1986. Some variations in the paratabulation of gonyaulacoid dinoflagellates. Palynology, 10:73-110.

Hochuli, P., and Kelts, K., 1980. Palynology of middle Cretaceous black clay facies from Deep Sea Drilling Project Sites 417-418 of the western North Atlantic. In Donnelly, T., Francheteau, J., Bryan, W., Robinson, P., Flower, M., Salisbury, M., et al., Init. Repts. DSDP, 51, 52, 53, Pt. 2: Washington (U.S. Govt. Printing Office), 897-935.

Jan du Chêne, R., Masure, E., Becheler, I, Biffi, U., De Vains, G., Fauconnier, D., Ferrario, R., Foucher, J.-Cl., Gaillard, M., Hochuli, P., Lachkar, G., Michoux, D., Monteil, E., Moron, J.-M., Rauscher, R., Raynaud, J.-F., Taugourdeau, J., and Turon, J.-L., 1986a. Guide Pratique pour la Détermination de Kystes de Dinoflagellés Fossiles: le Complexe Gonyaulacysta: Bull. Cent. Rech. Explor.-Prod. ElfAquitaine, 12.

Jan du Chêne, R., Becheler, I., Helenes, J., and Masure, E., 1986b. Les genres Diacanthum, Exiguisphaera, Occisucysta et Tehamadinium gen. nov. (kystes fossiles de Dinoflagellés). Cah. Micropaleontol., 1(3-4):5-66.

Leckie, R. M., 1984. Mid-Cretaceous planktonic foraminiferal biostratigraphy off central Morocco. In Hinz, K., Winterer, E. L., et al., Init. Repts. DSDP, 79: Washington (U.S. Govt. Printing Office), 579-620.

Lentin, J. K., and Williams, G. L., 1973. Fossil Dinoflagellates: Index to Genera and Species: Geol. Surv. Can. Pap., 73-42. 1975. Fossil dinoflagellates: index to genera and species, Suppl. 1. Can. J. Bot., 53:2147-2157. 1981. Fossil Dinoflagellates: Index to Genera and Species: Bedford Inst. Oceanogr. Rept. BI-R-81-12.

1985. Fossil Dinoflagellates: Index to Genera and Species: Can. Tech. Rept. Hydro. Ocean. Sci., 60.

Loeblich, A. R., Jr., and Loeblich, A. R., III, 1966. Index to the Genera and Subgenera, and Sections of the Pyrrhophyta. Univ. Miami, Stud. Trop. Oceanogr., 3.

Lucas-Clark, J. 1984. Morphology of species Litosphaeridium (Cretaceous, Dinophyceae). Palynology, 8:165-193.

Manum, S., and Cookson, I. C., 1964. Cretaceous microplankton in a sample from Graham Island, Arctic Canada, collected during the second "Fram"-Expedition (1898-1902). With notes on microplankton from the Hassel Formation, Ellef Ringnes Island. Ny Ser. MatNat. Schrifter utgitt av Det Norske Videnskaps-Akad. Oslo, 17:1-35.

Morgan, R., 1980. Palynostratigraphy of the Australian Early and middle Cretaceous. Geol. Surv. New South Wales, Palaeontol. Mem., 18:1-153.

Mullins, H. T., and Lynts, G. W., 1977. Origin of the northwestern Bahama platform: review and reinterpretation. Geol. Soc. Am. Bull., 88:1447-1461.

Pocock, S. A., 1972. Palynology of the Jurassic sediments of western Canada. Part 2. Marine species. Palaeontology, 137(B):85-153.

Sarjeant, W.A.S., 1962. Microplankton from the Ampthill Clay of Melton, South Yorkshire. Palaeontology, 5:478-497.

1966. Further dinoflagellate cysts from the Speeton Clay. Bull. Br. Mus. Nat. Hist., Geol., Suppl., 3:199-214.

1970. The genus Spiniferites Mantell, 1850 (Dinophyceae). Grana, 10:74-78.

Sheridan, R. E., Crosby, J., Bryan, G., and Stoffa, P., 1981. Stratigraphy and structure of southern Blake Plateau, northern Florida Straits, and northern Bahama Platform from multichannel seismic reflection data. AAPG Bull., 65:2571-2593.

Singh, Ch., 1983. Cenomanian Microfloras of the Peace River Area, Northwestern Alberta. Res. Counc. Alberta, 44.

Stover, L. E., and Evitt, W. R., 1978. Analyses of Pre-Pleistocene, Organic-walled Dinoflagellates. Stanford Univ. Publ., Geol. Sci., 15.

Wall, D., Dale, B., Lohmann, G. P., and Smith, W. K., 1977. The environmental and climatic distribution of dinoflagellate cysts in modern marine sediments from regions in the North and South Atlantic Ocean and adjacent seas. Mar. Micropaleontol., 2:121-200.

Wetzel, O., 1933a. Die inorganischer Substanz erhaltenen Mikrofossilien des baltischen Kreide-Feuersteins mit einem sediment-petrographischen und strategraphischen Anhang. Palaeontographica, 77(A): 141-188.

1933b. Die inorganischer Substanz erhaltenen Mikrofossilien des baltischen Kreide-Feuersteins mit einem sediment-petrographischen und strategraphischen Anhang. Palaeontographica, 78(A):1110.

White, H. H., 1842. On fossil Xanthidia. Microsc., London, 11:35-40.

Williams, G. L., 1975. Dinoflagellate and spore stratigraphy of the Mesozoic-Cenozoic, offshore eastern Canada. Geol. Surv. Can. Pap. 74-30, 2:107-161.

1978. Palynological biostratigraphy, Deep Sea Drilling Project Sites 367 and 370, Leg 41. In Lancelot, Y., Seibold, E., et al., Init. Repts. DSDP, Suppl. to Vols. 38-41: Washington (U.S. Govt. Printing Office), 783-815.

Williams, G. L., and Bujak, J. P., 1985. Mesozoic and Cenozoic dinoflagellates. In Bolli, H. M., Saunders, J. B., and Perch-Nielsen, K. (Eds.), Plankton Stratigraphy: Cambridge (Cambridge Univ. Press), 847-964.

Yun, H.-S., 1981. Dinoflagellaten aus der Oberkreide (Santon) von Westfalen. Palaeontographica, 177(B):1-89.

Date of initial receipt: 25 November 1986

Date of acceptance: 8 June 1987

Ms 101B-127

APPENDIX

Sample List

Hole 627B (interval in $\mathrm{cm}$ ) 101-627B-29X-2, 50-52 101-627B-33X-2, 50-52 101-627B-34X-3, 50-52 $101-627 \mathrm{~B}-38 \mathrm{X}-1,50-51$ 101-627B-38X-2, 50-52 101-627B-38X-3, 50-52 101-627B-38X-4, 50-52 101-627B-39X-2, 50-52 101-627B-39X-4, 50-52 101-627B-39X-6, 50-52 101-627B-40X-5, 50-52 101-627B-41X-1, 50-52 101-627B-41X-3, 50-52 101-627B-41X-6, 50-52 101-627B-43X-2, 50-52 101-627B-43X-6, 50-52 101-627B-46X-5, 50-52 101-627B-47X-3, 50-52 101-627B-47X-5, 50-52 101-627B-49X-1, 9-11 101-627B-49X-1, 29-31 101-627B-52X, CC 101-627B-54X, CC 101-627B-57X, CC

Hole 635B (interval in $\mathrm{cm}$ ) 101-635B-8R, CC 101-635B-9R-1, 53-55 101-635B-10R-2, 75-76 101-635B-11R-1, 78-80 101-635B-11R-2, 134-136 101-635B-13R-1, 67-68 101-635B-13R-2, 35-37 101-635B-13R-2, 40-42 101-635B-14R-3, 110-112 101-635B-14R-3, 146-148 


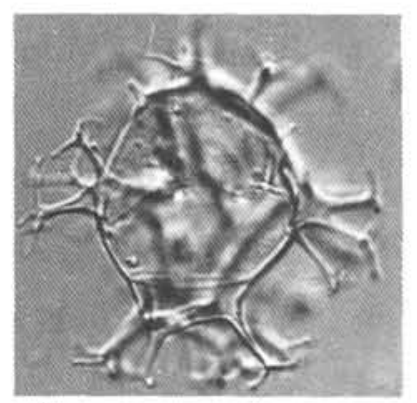

1

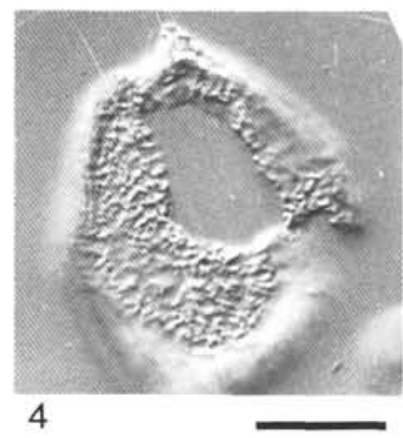

4
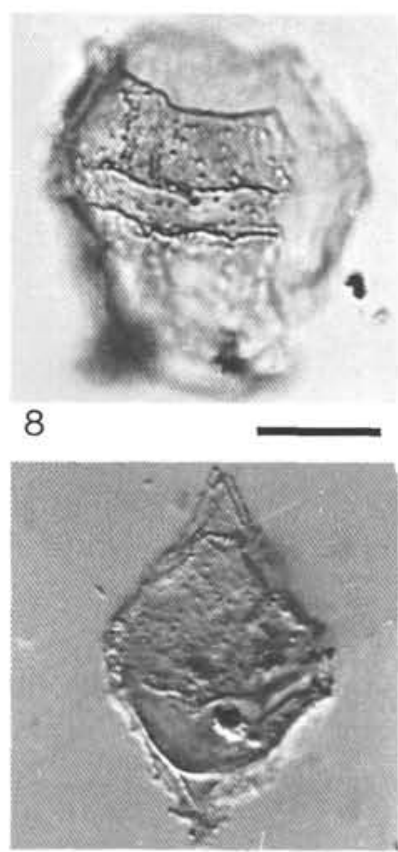

11B

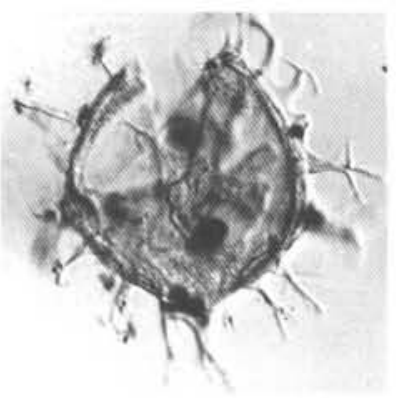

2

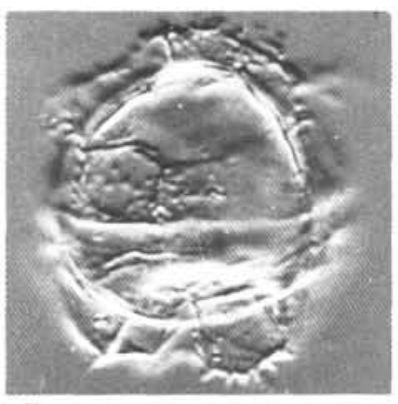

5

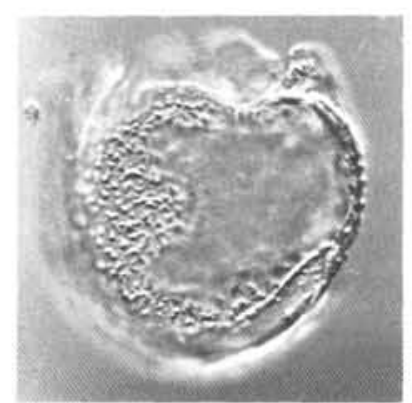

9

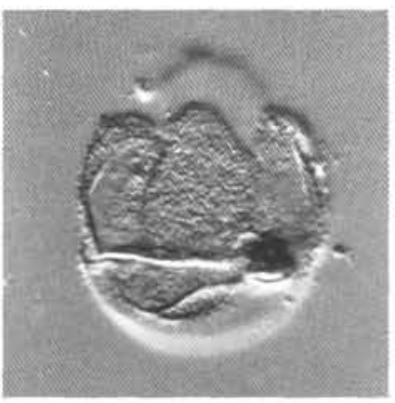

12

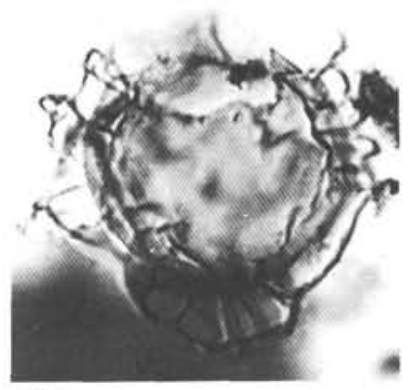

$3 A$

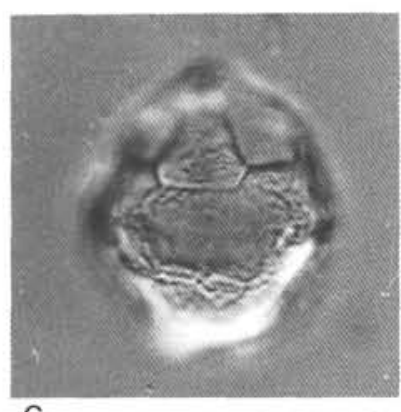

6

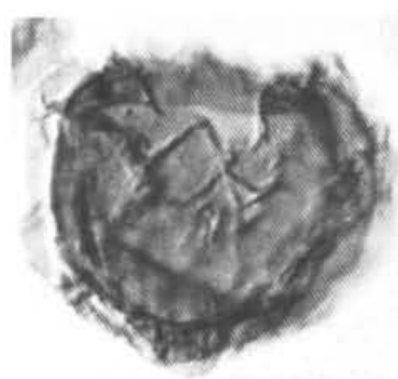

10

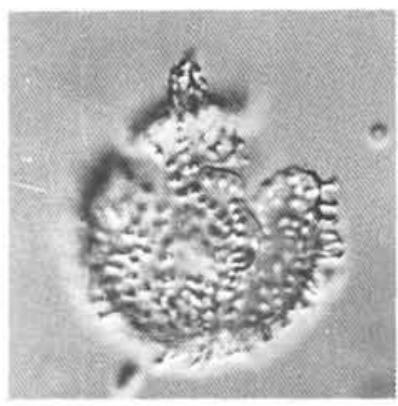

13

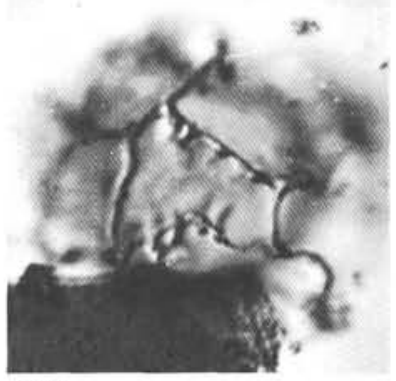

$3 B$
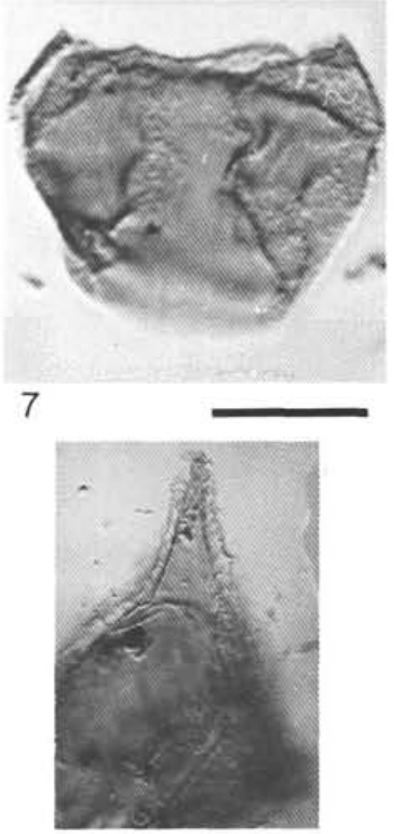

$11 \mathrm{~A}$

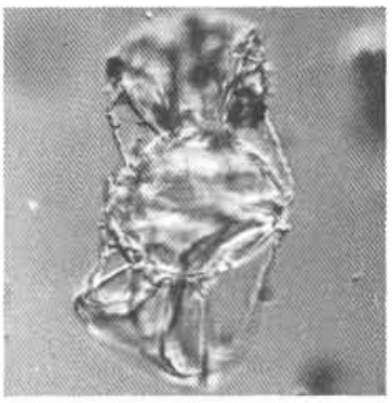

14

Plate 1. (Scale bar $=20 \mu \mathrm{m}$.) 1. Achomosphaera ramulifera; length, $60 \mu \mathrm{m}$; optical section; slide 2: LM 35-36; Sample 101-627B-38X-3, 50-52 $\mathrm{cm}$. 2. Achomosphaera sagena; length, $71 \mu \mathrm{m}$; general view; slide 3: Z 43; Sample 101-627B-47X-5, 50-52 cm. 3. Adnatosphaeridium tutulosum; length, $48 \mu \mathrm{m} ; A$, ventral face; $B$, dorsal face, interior view; slide 1: Z 34; Sample 101-635B-11R-1, 78-80 cm. 4. Aldorfia deflandrei; length, $52 \mu \mathrm{m}$; dorsal face; slide 1: NO 50-51; Sample 101-627B-38X-4, 50-52 cm. 5. Angustidinium acribes; length, $39 \mu$ m; dorsal face, interior view, slide 1: V 34; Sample 101-627B-38X-3, 50-52 cm. 6. Ascodinium diversum; length, $48 \mu \mathrm{m}$; dorsal face; slide 1: Q 24-25; Sample 101-635B-13R-2, 35-37 $\mathrm{cm}$. 7. Ascodinium implanum; length, $36 \mu \mathrm{m}$; dorsal face, interior view, slide 2: P 48-49; Sample 101-635B-13R-2, 40-42 cm. 8. Ascodinium verrucosum ssp. verrucosum; length, $54 \mu \mathrm{m}$; dorsal face, slide 1: UV 40-41; Sample 101-635B-13R-2, 40-42 cm. 9. Canningia sp. A. MPK 1681, sensu Davey, 1979; length, $72 \mu \mathrm{m}$; focus on the granulations; slide 3: UV 42-43; Sample 101-635B-11R-1, 78-80 cm. 10. Cassiculosphaeridia reticulata; length, $45 \mu \mathrm{m}$; ventral face; slide 1: RS 32-33; Sample 101-635B-14R-3, 146-148 cm. 11 . Cepadinium? sp. BAHA; length, $64 \mu \mathrm{m} ; A$, detail of the apical horn with endophragm, periphragm, and ectophragm; $B$, general view; slide 2: P 40; Section 101-627B-57X, CC. 12. Chlamydophorella discreta; length, $40 \mu \mathrm{m}$; dorsal face, interior view; slide 1: M 28; Sample 101-627B-38X-4, 50-52 cm. 13. Chlamydophorella nyei; length, $35 \mu \mathrm{m}$; ventral face; slide 1: L 33; Sample 101-635B-13R-2, 35-37 cm. 14. Codoniella psygma; length, $84 \mu \mathrm{m}$; optical section; slide 3: X 25; Sample 101-635B-14R-3, 110-113 cm. 


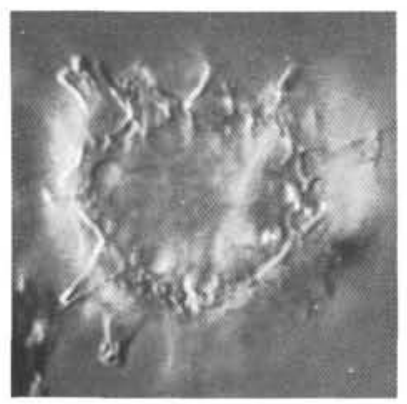

1
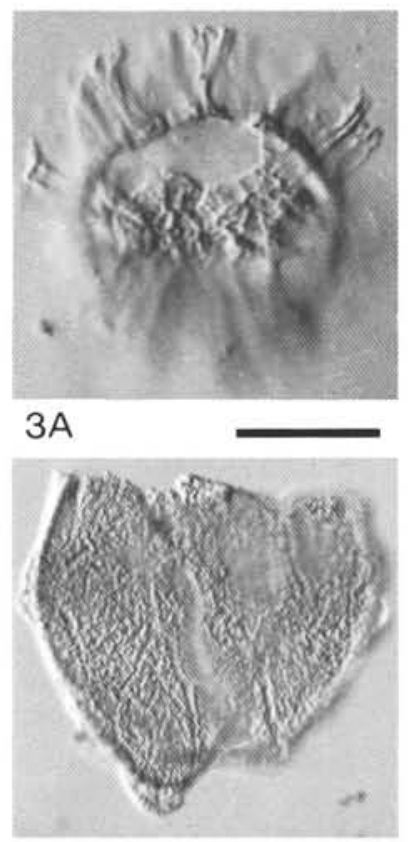

5

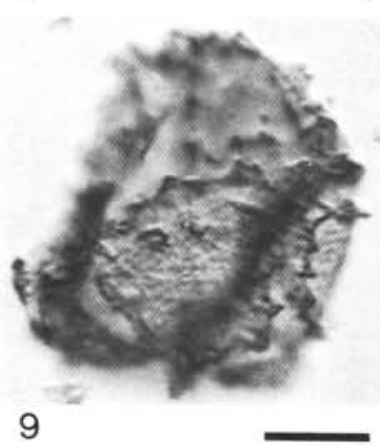

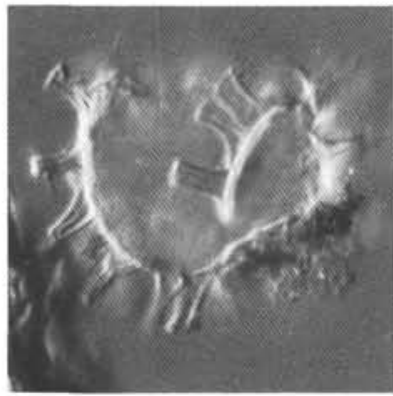

$2 \mathrm{~A}$

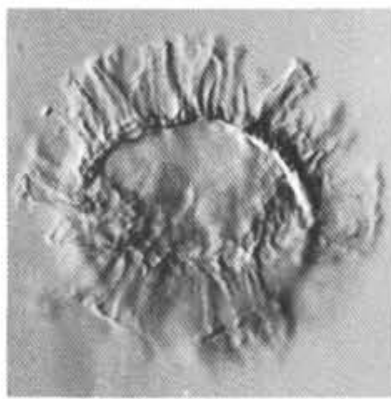

3B

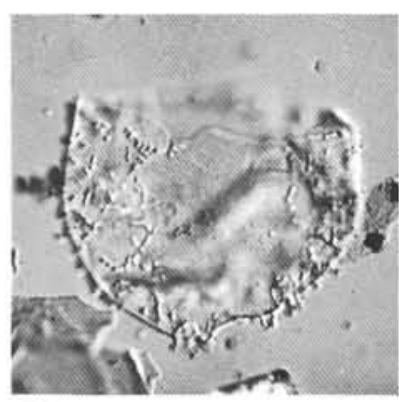

6

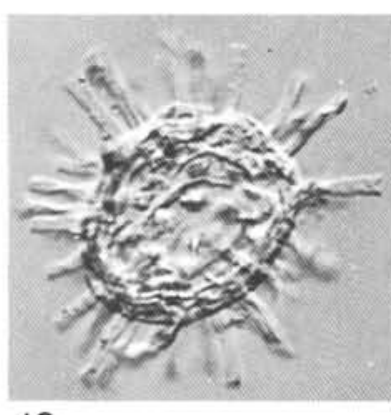

10
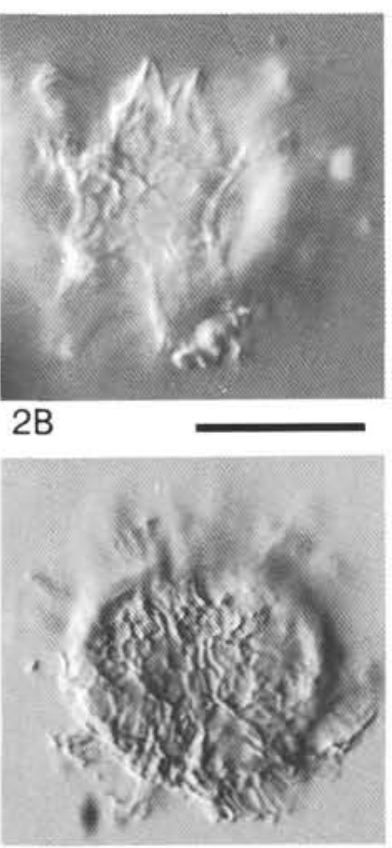

$3 C$

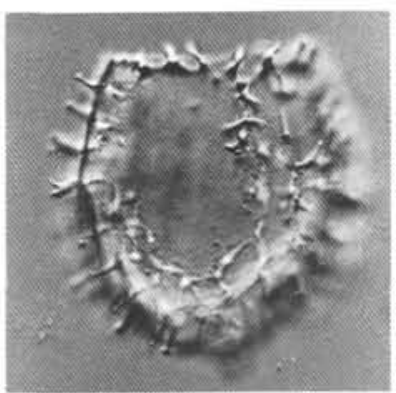

7

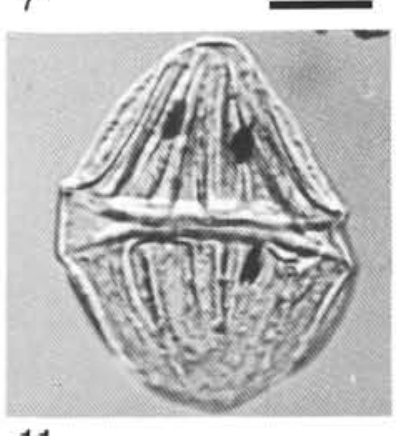

11

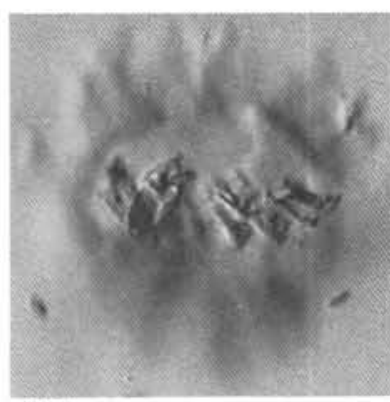

2C

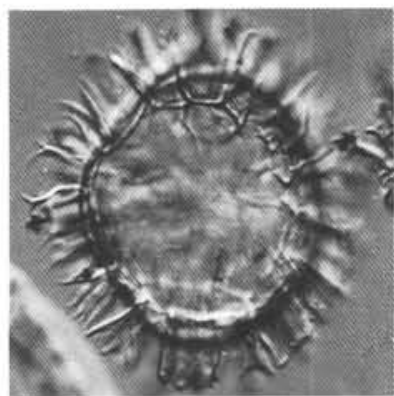

4

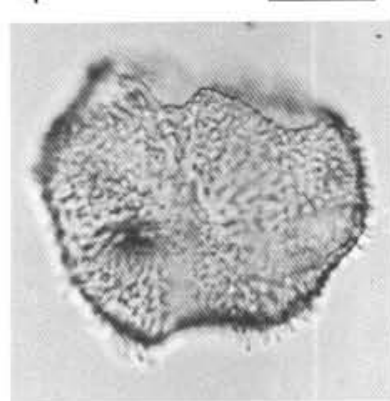

8

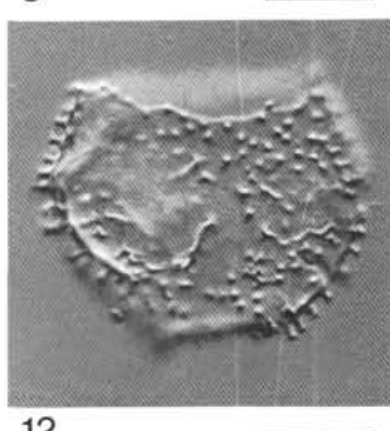

12

Plate 2. (Scale bar $=20 \mu \mathrm{m}$.) 1. Compositosphaeridium? bahamaensis n. sp.; length, $36 \mu \mathrm{m}$; holotype; $A$, ventral face; $B$, optical section; operculum inside the central body; $C$, dorsal face, interior view; slide 3: TU 43-44; Sample 101-627B-38X-2, 50-52 cm. 2. Compositosphaeridium? bahamaensis $\mathrm{n}$. sp.; length $48 \mu \mathrm{m} ; A$, focus on the "polytubular" precingular processes; $B$, focus on the archeopyle; $C$, focus on the cingular processes; $D$, focus on the reticulate ridges of the periphragm; slide 3: X 28; Sample 101-627B-47X-5, 50-52 cm. 3. Coronifera striolata; length, $72 \mu \mathrm{m}$; focus on the antapical process; slide 1: R 38-39; Sample 101-627B-46X-5, 50-52 cm. 4. Cyclonephelium chabaca; length, $78 \mu \mathrm{m}$; ventral face, interior view; slide 1: VW 26-27; Sample 101-627B-43X-6, 50-52 cm. 5. Cyclonephelium compactum; length, $68 \mu$ m; ventral face, interior view; slide 1: Q 39-40; Sample 101-627B-47X-5, 50-52 cm. 6. Cyclonephelium distinctum; length, $68 \mu \mathrm{m}$; ventral face; slide 1: Z 39; Sample 101-627B-38X-3, 50-52 $\mathrm{cm}$. 7. Cyclonephelium hystrix; length, $54 \mu \mathrm{m}$; ventral face, interior view; slide 3: LM 40; Sample 101-635B-11R-1, 78-80 cm. 8. Danea chibanis; length, $69 \mu \mathrm{m}$; right-lateral side; slide 3: K 40-3; Sample 635B-14-3, 146-148 cm. 9. Dapsilidinium laminaspinosum; length, $48 \mu \mathrm{m}$; general view; slide 2: Y 38; Sample 101-635B-14R-3, 110-113 cm. 10. Dinogymnium microgranulosum; length, $59 \mu \mathrm{m}$; slide 3: MN 25-26; Sample 101-627B$38 \mathrm{X}-4,50-52 \mathrm{~cm}$. 11. Epelidosphaeridia spinosa; length, $36 \mu \mathrm{m}$; dorsal face, interior view; slide 1: PQ 50; Sample 101-627B-38X-4, 50-52 cm. 

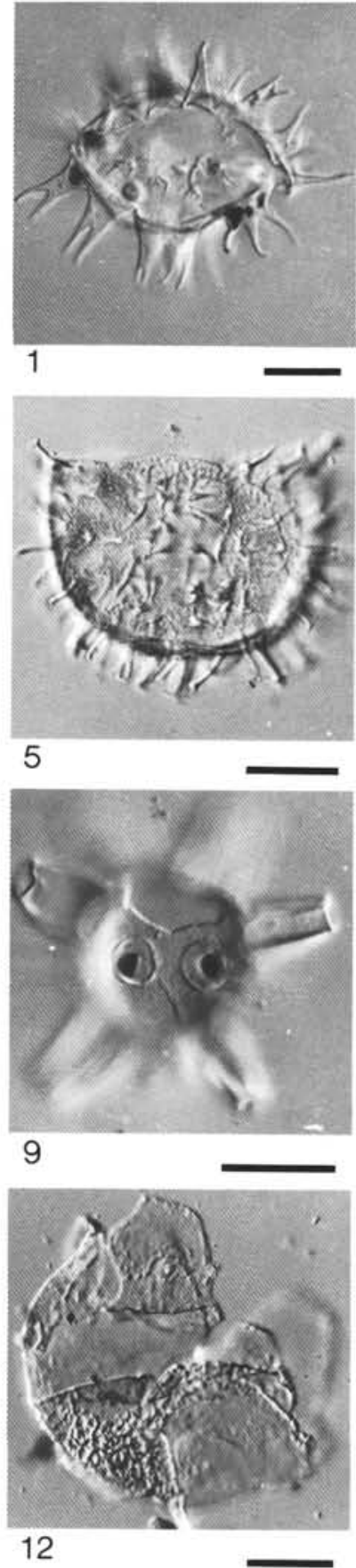
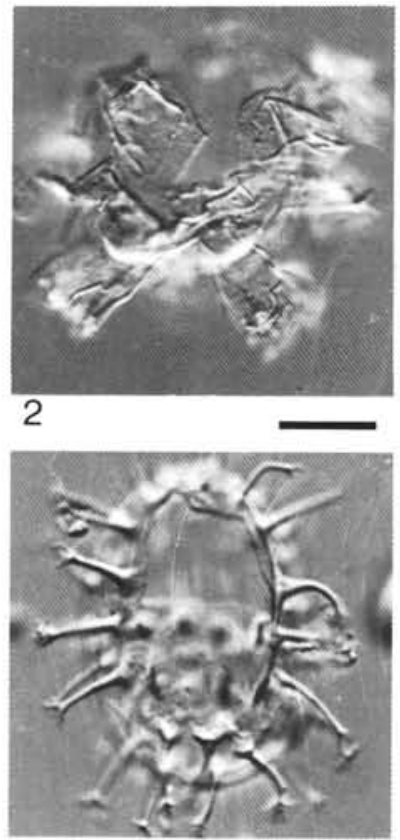

6

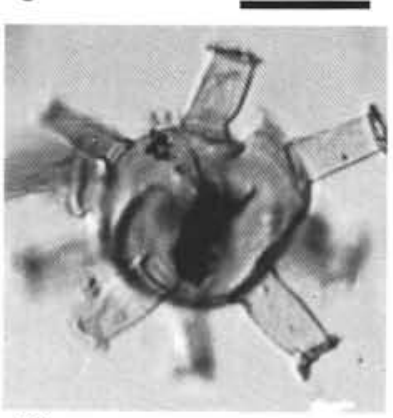

10

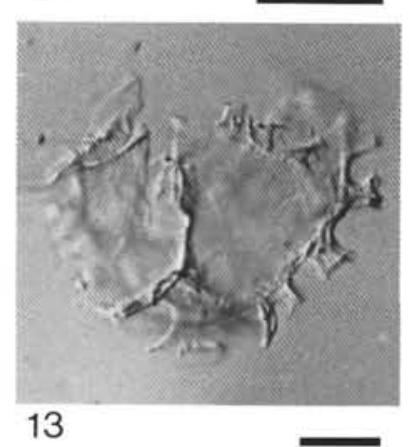

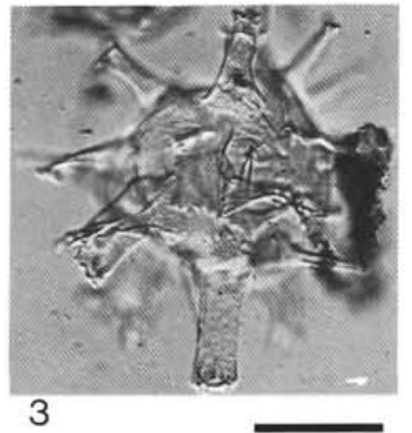

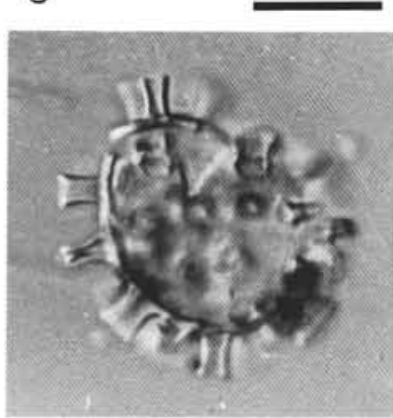

7

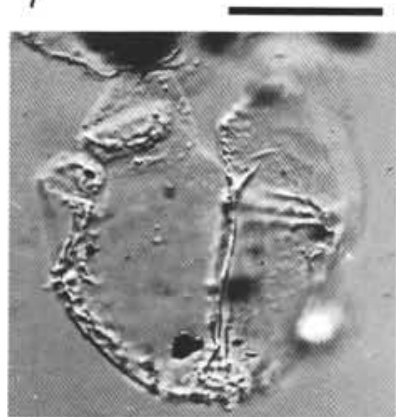

11A

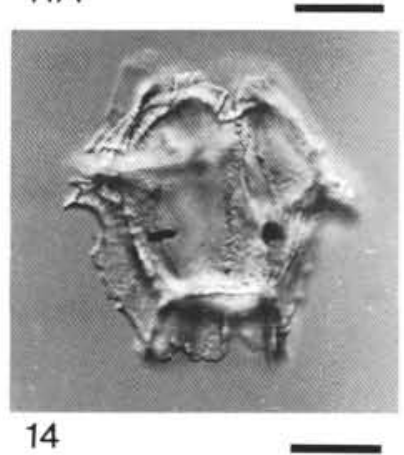

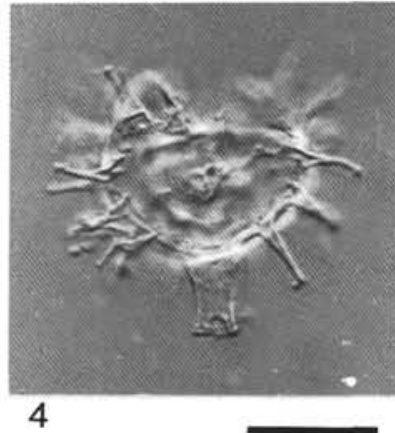

4

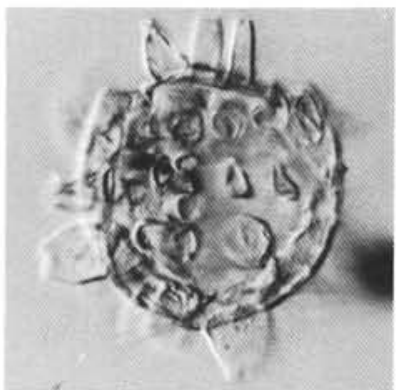

8

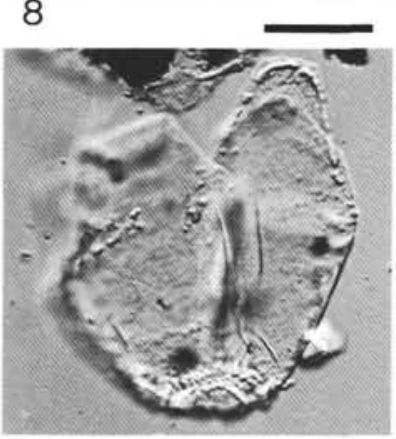

11B

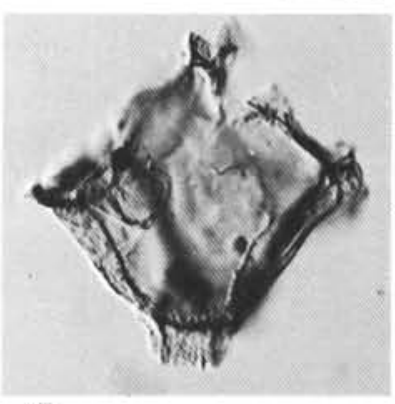

15

Plate 3. (Scale bar $=20 \mu \mathrm{m}$.) 1. Florentinia clavigera; length, $84 \mu \mathrm{m}$; general view; slide 3: KL 29-30; Sample 101-627B-38X-4, 50-52 cm. 2. Florentinia deanei; length, $96 \mu \mathrm{m}$; general view; slide 1: V 26; Sample 101-627B-47X-5, 50-52 cm. 3. Florentinia mantelli; length, $76 \mu \mathrm{m}$; general view; slide 1: YZ 26-27; Sample 101-627B-38X-3, 50-52 cm. 4. Florentinia radiculata; length, $44 \mu \mathrm{m}$; general view; slide 1: Y 32-33; Sample 101-627B-38X-3, 50-52 cm. 5. Heterosphaeridium? heteracanthum; length, $48 \mu \mathrm{m}$; dorsal face; slide 3: WX 43-44; Sample 101-627B-38X-4, 50-52 $\mathrm{cm}$. 6. Kiokansium williamsii; length, $61 \mu \mathrm{m}$; focus dorsal face with $2 \mathrm{P}$ 4-5 archeopyle; slide 1: KL 49-50; Sample 101-627B-47X-3, 50-52 cm. 7. Litosphaeridium arundum; length, $38 \mu \mathrm{m}$; general view; slide 2: S 38; Sample 101-635B-13R-2, 35-37 cm. 8. Litosphaeridium conispinum; length, $64 \mu \mathrm{m}$; low focus; slide 2: Z 43; Sample 101-635B-13R-2, 35-37 cm. 9. Litosphaeridium siphoniphorum ssp. siphoniphorum; length, $55 \mu \mathrm{m}$; lateral view; slide 1: Y 43-44; Sample 101-627B-38X-1, 50-52 cm. 10. Litosphaeridium sp. BAHA; length, $56 \mu$ m; general view; slide 3: Z 34-35; Sample 101-627B-47X-5, 50-52 cm. 11. Maghrebinia breviornata n. sp.; length, $72 \mu \mathrm{m}$; holotype; $A$, ventral face, with adnate operculum; $B$, dorsal face, interior view; slide 1: J 49; Sample 101-627B-47X-5, 50-52 cm. 12. Maghrebinia breviornata; length, $72 \mu \mathrm{m}$; focus on the adnate operculum; slide 1: X 26; Sample 101-627B-43X-6, 50-52 cm. 13. Maghrebinia chleuh; length, $73 \mu \mathrm{m}$; general view; slide 2: NO 50-51; Sample 101-627B-49X-1, 29-31 cm. 14. Maghrebinia perforata ssp. mirabilis; length, $64 \mu \mathrm{m}$; low focus; slide 3: DE 34-35; Sample 101-635B-11R-1, 78-80 cm. 15. Maghrebinia perforata ssp. perforata; length, $66 \mu \mathrm{m}$; low focus; slide 1: Q 48; Sample 101-627B-47X-3, 50-52 cm. 

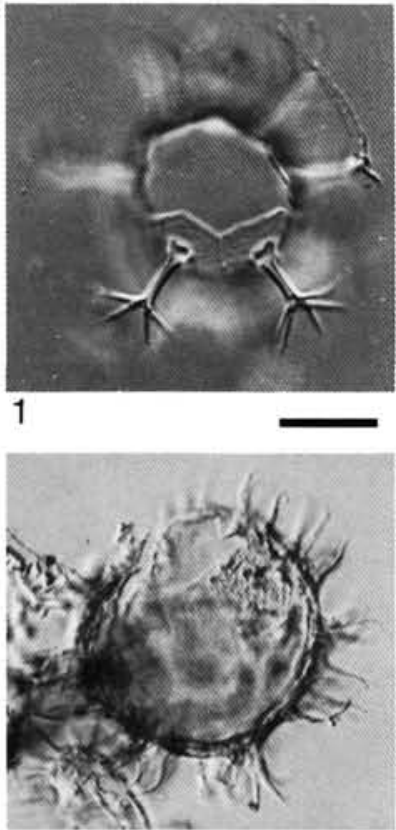

5

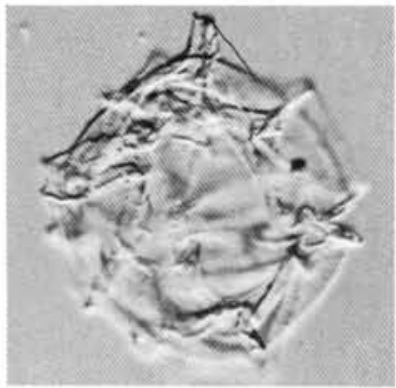

8

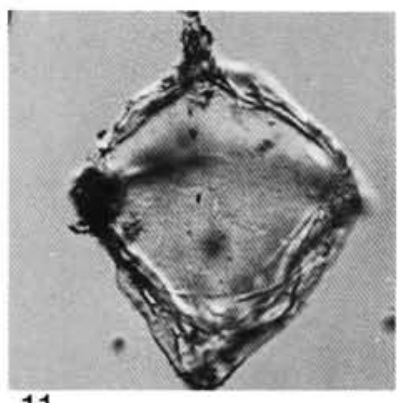

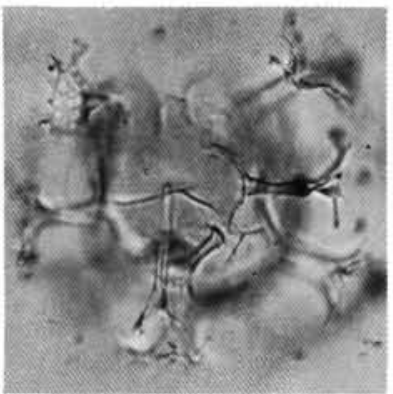

2

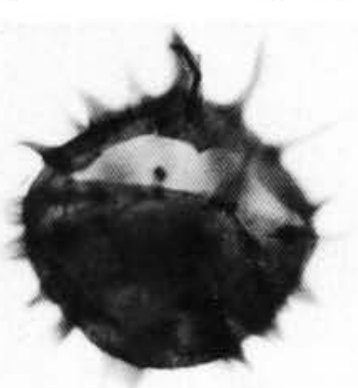

$6 \mathrm{~A}$

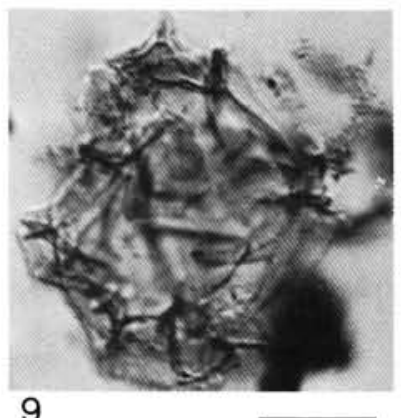

9

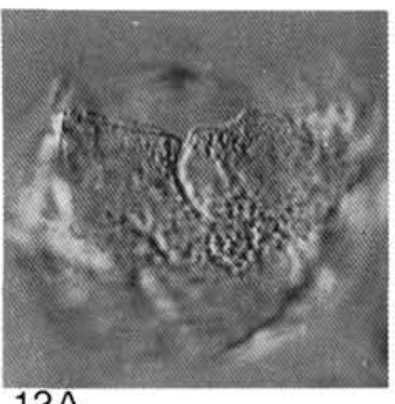

11

$12 \mathrm{~A}$

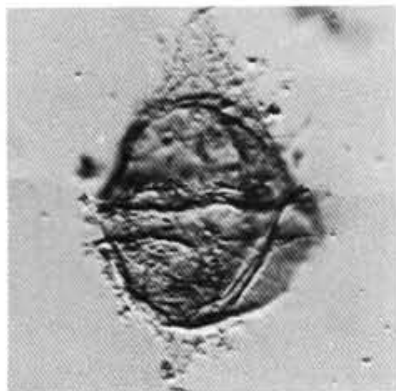

3

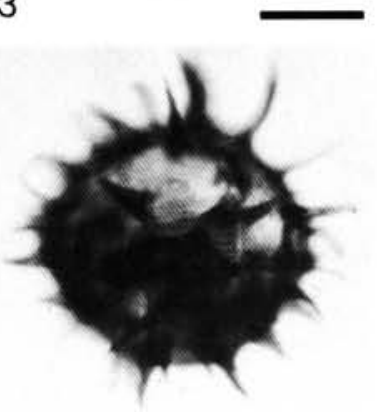

$6 B$

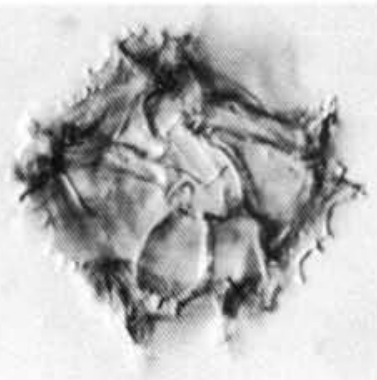

$10 \mathrm{~A}$

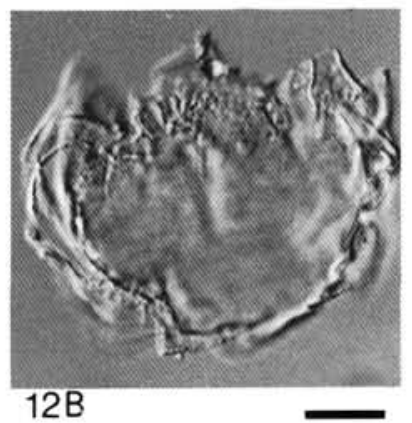

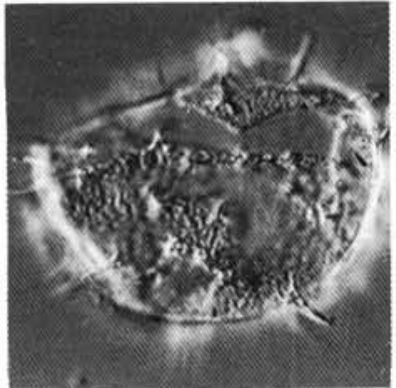

4

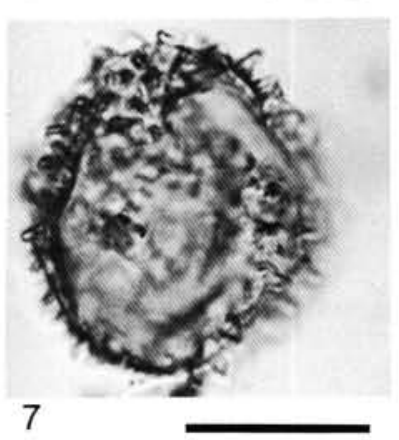

7

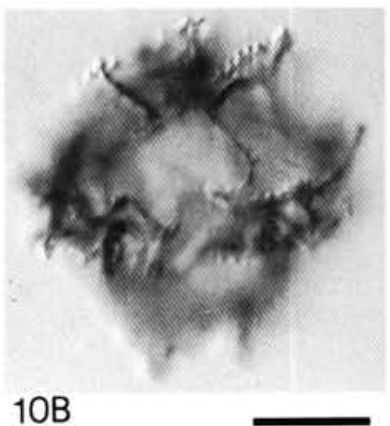

10B

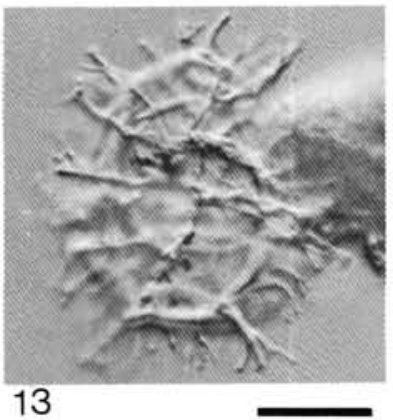

Plate 4. (Scale bar $=20 \mu \mathrm{m}$.) 1. Oligosphaeridium? asterigerum; length, $72 \mu \mathrm{m}$; lateral side; slide 1: K 42; Sample 101-635B-13R-2, 35-37 cm. 2. Oligosphaeridium pulcherrimum; length, $72 \mu \mathrm{m}$; focus on the distal end of the processes; slide 1: FG 47; Section 101-627B-57X, CC. 3. Palaeohystrichophora infusorioides; length, $68 \mu \mathrm{m}$; general view; slide 2: Z 29; Sample 101-635B-14R-3, 146-148 cm. 4. Pervosphaeridium paucispinum; length, $52 \mu \mathrm{m}$; high-focus dorsal view; slide 1: HJ 41-42; Sample 101-627B-38X-3, 50-52 cm. 5. Pervosphaeridium truncatum; length, $76 \mu \mathrm{m}$; high-focus archeopyle 2P 3-4; slide 1: RS 31-32; Sample 101-627B-46X-5, 50-52 cm. 6. Pervosphaeridium truncatum; length, $84 \mu \mathrm{m}$; holotype; $A$, dorsal face, archeopyle, type 2P 3-4; $B$, ventral face, interior view; stored in the British Museum (N.H.), London. 7. Protoellipsodinium seghiris; length, $36 \mu \mathrm{m}$; slide 1: Y 36; Sample 101-635B-11R-1, 78-80 cm. 8. Pterodinium cingulatum ssp. cingulatum; length, $60 \mu \mathrm{m}$; general view; slide 2: D 33; Section 101-635B-8R, CC. 9. Pterodinium cingulatum ssp. intermedium; length, $64 \mu \mathrm{m}$; general view; slide 1: D 33-34; Sample 101-635B-11R-2, 134-136 cm. 10. Pterodinium cf. cornutum sensu Below, 1981; length, $54 \mu \mathrm{m}$; $A$, ventral face; $B$, dorsal face; interior view; slide 2: MN 25; Sample 101-635B-14R-3, 146-148 cm. 11. Scriniodinium cf. campanula; length, $76 \mu \mathrm{m}$; general view, short spines along the parasutures of the cingulum, operculum inside the inner body; slide 3: T 32-33; Sample 101-627B-47X-5, 50-52 cm. 12. Senoniasphaera cf. rotundata; length, $64 \mu \mathrm{m} ; A$, dorsal face; $B$, ventral face; interior view; slide 3: K 41-42; Sample 101-627B-38X-4, 50-52 cm. 13. Spiniferites lenzi; length, $55 \mu \mathrm{m}$; high focus; slide 2: EF 38; Section 101-635B-8R, CC. 

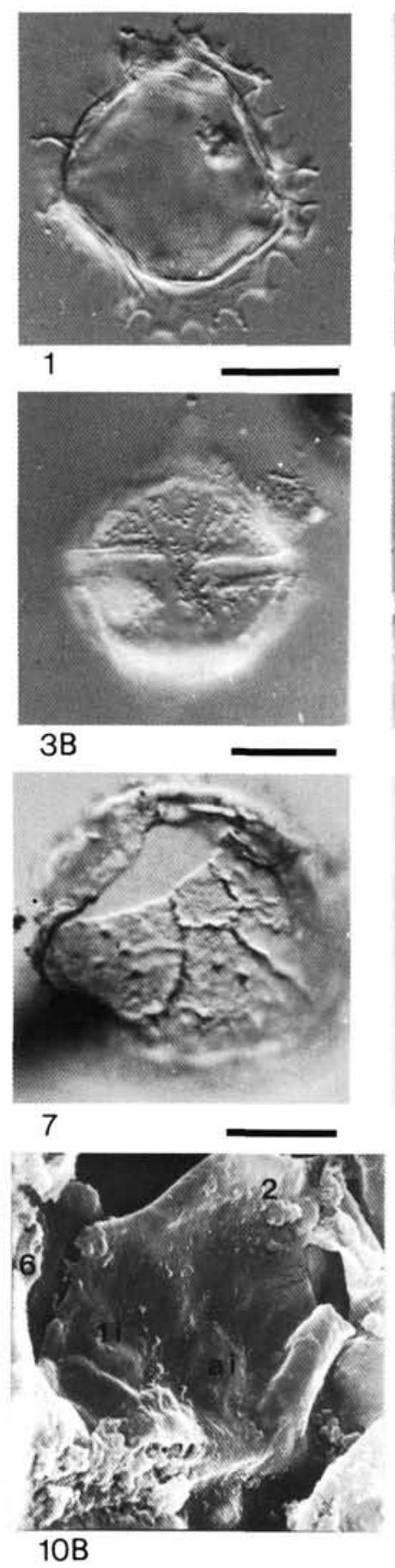
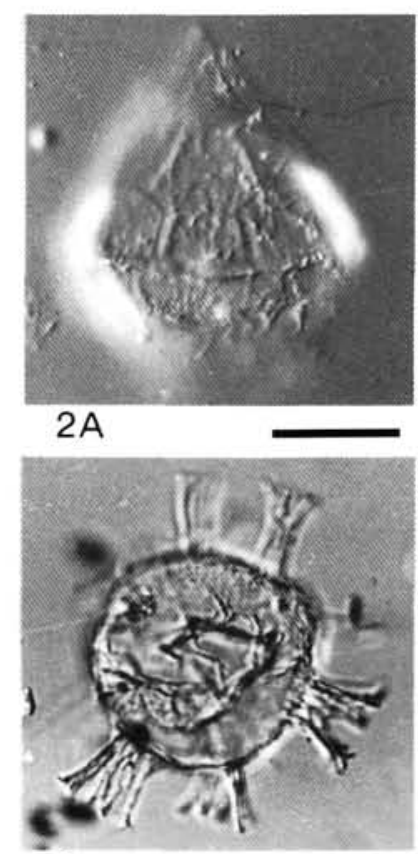

4

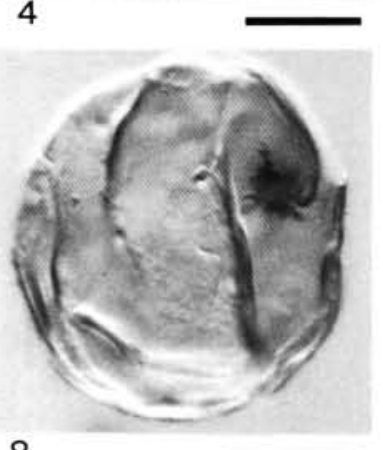

8

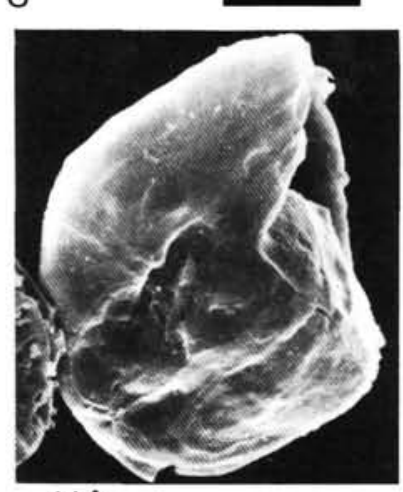

$11 \mathrm{~A}$
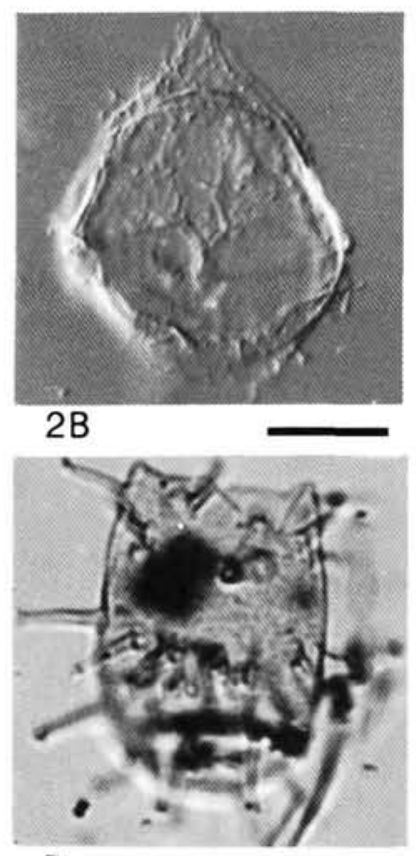

5

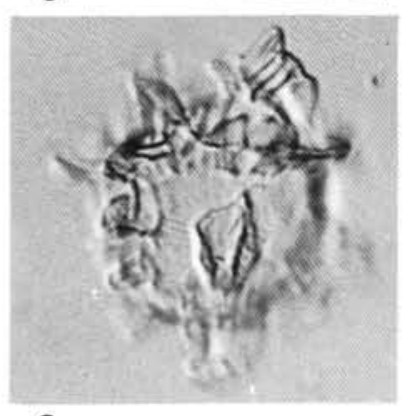

9
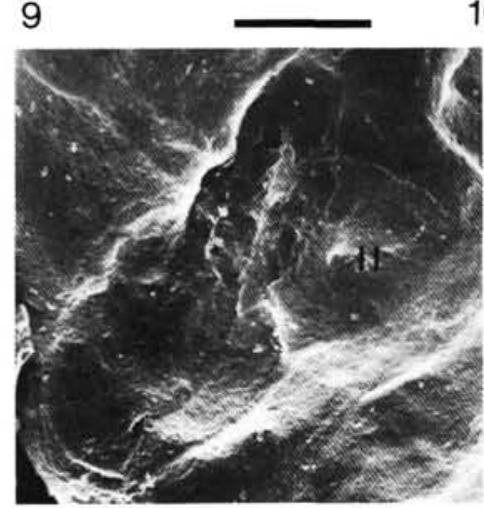

$11 \mathrm{~B}$

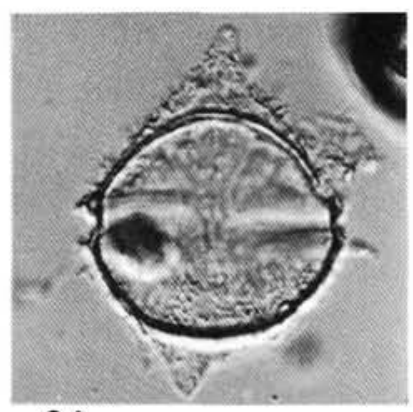

$3 \mathrm{~A}$

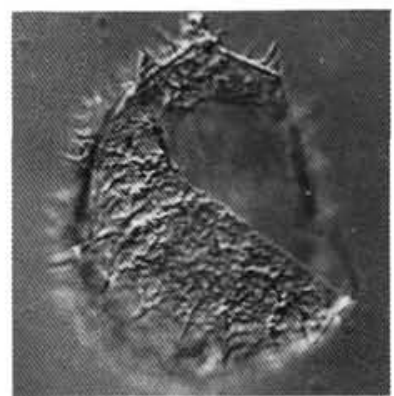

6

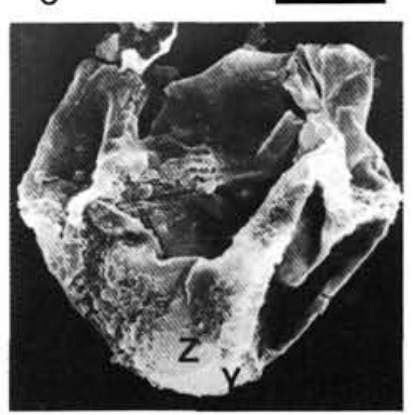

$10 \mathrm{~A}$

Plate 5. (Scale bar $=20 \mu \mathrm{m}$.) 1. Spiniferites cf. wetzeli; length, $52 \mu \mathrm{m}$; optical section; slide 3: Z 42; Sample 101-627B-38X-4, 50-52 cm. 2. Subtilisphaera? habibi n. sp.; length, $65 \mu \mathrm{m}$; holotype; $A$, dorsal view, see intratabular spines, pandasutures, and endoarcheopyle; $B$, ventral face, interior view; slide 1: NO 34-35; Sample 101-627B-39X-6, 50-52 cm. 3. Subtilisphaera? habibi n. sp.; length, $68 \mu$ m; $A$, optical section, accumulation body(?) in the central body; $B$, ventral face, interior view, see intratabular spines, pandasutures, and parasutural ridges; slide 2: VW 45; Section 101627B-54X, CC. 4. Systematophora? sp. MAZ; diameter, $65 \mu \mathrm{m}$; slide 2: K 41-42; Sample 101-635B-13R-2, 35-37 cm. 5. Tanyosphaeridium variecalamus; length, $45 \mu \mathrm{m}$; ventral face; slide 1: UV 49; Sample 101-627B-47X-5, 50-52 cm. 6. Tehamadinium mazaganensis; length, $70 \mu$ m; dorsal lateral face; slide 1: X 40-41; Sample 101-635B-13R-2, 35-37 cm. 7. Tehamadinium tenuiceras; diameter, $56 \mu$ m; apical view; slide 1: XY 25-26; Sample 101-635B-14R-3, $110-112 \mathrm{~cm}$. 8. Forma A; length, $52 \mu \mathrm{m}$; optical view; slide 3: L 45; Sample 101-627B-47X-5, 50-52 cm. 9. Forma B; length, $52 \mu \mathrm{m}$; lateral view; slide 1: UV 27; Sample 101-627B-38X-4, 50-52 cm. 10. Maghrebinia breviornata $\mathrm{n}$. sp.; $A$, ventral face, $\times 700 ; B$, detail of the undifferentiated ventral area, see the $6 / 1 \mathrm{i}$ accessory archeopyle suture and the alignment of granules; $\mathrm{A} /$ ai arrangement, $\times 2000$; Sample 101627B-43X-6, 50-52 cm. 11. Forma A, SEM; $A$, general view, $\times 350 ; B$, detail of the sulcus, $\times 750$; Sample 101-627B-43X-6, 50-52 cm. 12. Subtilisphaera? habibi, SEM, $\times 600$; ventral view; Sample 101-627B-38X-3, 50-52 cm. 